Estudios sobre armas antiguas, arte militar y vida cultural en oriente y occidente

XXXI (2011), pp. 7-42

ISSN : 0436-029X

doi: 10.3989/gladius.2011.0001

\title{
ANCIENT BRONZE HORSE MUZZLES OF THE IBERIAN PENINSULA
}

\author{
BOZALES Y MUSEROLAS DE BRONCE EN LA PENÍNSULA IBÉRICA
}

POR

Ignasi Garcés Estallo* and Raimon Graells Fabregat**

\begin{abstract}
RESUMEN
Horse muzzles and Bronze muzzles are unique equestrian tools that have been referred to in scattered accounts throughout history. Nevertheless, the majority of these objects have received short descriptions and an overall study is still missing. The lack of a comprehensive study hinges on the over looked importance of these items and the superficial manner that have characterized their documentation. Both these reasons have limited observations on chronology and archaeological investigation. The recent identification of new unpublished exemplars among the Museums' collections in Barcelona and Lleida has encouraged the authors of this paper to start a new study dedicated to these objects. Starting from a catalogue inclusive of all muzzles and muzzles currently known in the Iberian Peninsula, an attempt will be made to propose an accurate description, typological classification and, for some of the items, a revision of the decorative scenes that have marked their place in bronze horse muzzle and muzzle chronology. The formal development and the chronological framework here proposed refer to those of the exemplars found in Greece and in Italy. The broadening of the geographical area will allow reconsideration of those social phenomena that have in the past determined the diffusion of elements in horse tack throughout most of the western Peninsula in the Mediterranean.
\end{abstract}

Los bozales y las muserolas en bronce para caballo constituyen unos excepcionales complementos ecuestres cuyo conocimiento se encuentra disperso en una extensa bibliografía. De muchos ejemplares apenas se ha publicado una breve descripción y nunca hasta el presente han sido objeto de un estudio monográfico, quizás por el desaliento que produce el desconocimiento de su procedencia en unos casos, o la superficial noticia del contexto de aparición en la mayoría de ellos, hecho que ha limitado las consideraciones cronológicas y de asociación. La identificación de nuevos ejemplares inéditos en los museos de Barcelona y Lleida ha animado a los autores a emprender un trabajo que por primera vez reúne y revisa los ejemplares conocidos de la Península Ibérica, para los que se propone una descripción normalizada, una clasificación tipológica y, en determinadas piezas, una sustancial revisión de las escenas decorativas y cronologías comúnmente admitidas. La seriación formal y la propuesta de datación implican la referencia de los ejemplares aparecidos en Grecia e Italia. Esa ampliación espacial conduce a replantear los agentes sociales que pueden estar detrás de la propagación de ese complemento ecuestre hasta la península más occidental del Mediterráneo.

\section{Keywords - Palabras Clave}

Horse; Horsemen; Harness; Muzzle; Cemeteries; Iberian; Warlike aristocracies; Mercenary; Equestrian society; Macedonia; Magna; Graecia; Roman Republic; Hispania.

Caballo; Jinetes; Bozal; Muserola; Necrópolis; Iberos; Aristocracias guerreras; Mercenario; Sociedad ecuestre; Macedonia; Magna Grecia; República romana; Hispania.

* Universitat de Barcelona, Dept. de Prehistòria, Historia Antiga i Arqueologia, c/ Montalegre 6-8, 08001 Barcelona. garces@ub.edu.

** Forschungsstipendiat der Alexander von Humboldt-Stiftung; Römisch-Germanisches Zentralmuseum, Ernst-Ludwig Plaz, 3. 55116, Mainz.graells@rgzm.de. 


\section{HORSE MUZZLE IN ANCIENT TIMES}

\subsection{SUGgESTIONS ABOUT THE USE OF HORSE MUZZLE IN LITERARY SOURCES}

Sometimes certain horses may attempt to bite their owner, their riders or even other horses (Anderson, 1961: 43; Hyland, 1990: 42; 2003: 58). This problem can be easily solved through the employment of a muzzle. The use of a protection, unlike one may think, is not universal, the use of horse-bits, which are necessary to keep the animal under complete control, do not automatically assume with them a halter or muzzle. Thus, every horse who attempts to bite must necessarily wear both muzzle and bridles (Argente et al., 2000: 70; Quesada, 2005: 100). This tendency towards both items has been noticed during the Antiquity: in order to avoid accidents, Xenophon suggested in his De equitatione ( $4^{\text {th }}$ century B.C.) that a horseman should teach his groom to use the muzzle consistently with the horse: «the groom must also know about putting the muzzle when he takes him out to be groomed or to the rolling-place. In fact he must always put the muzzle on when he leads him anywhere without a bridle. For the muzzle prevents him from biting without hampering his breathing; and, moreover, when it is put on, it goes far towards preventing any propensity to mischief» (X, Eq., 5, 3) ${ }^{1}$.

From the quotation above we can assume that for those horses whose behaviour was considered dangerous the muzzle was used more frequently than other devices. Simple materials - like rope, leather or wicker - and not necessarily metals were employed to fabricate a muzzle, the second ones being more an exception (this is not the case of horse-bits, which are most always metal objects in order to contrast the animal's strength). It is not surprising, then, that we know about a relative high amount of horse-bits coming from Ancient Near-East, proto-historic Europe or Greek and Roman regions, whereas the number of preserved bronze muzzles is considerably minute and restricted to the Mediterranean area. An explanation for this fact may be understood if we consider cultural and military traditions as well as the social prestige of horses' owners.

\subsection{MuZZLES AND OTHER SIMILAR EQUIPMENTS IN LITERARY SOURCES}

To understand muzzles it is important to know their story and their use. With this in mind we can not leave aside the analysis of the ancient terminology used by contemporary authors to describe these objects. The following is an attempt to provide a terminological reconstruction based on a review of headwords and descriptions that can be found in the work written by Daremberg and Saglio (1887), including some small additions. Unfortunately in the description of muzzles there was a considerable lack of precision to indicate them as specific elements; essentially many words were employed to define the object to which we refer when we use the word «muzzle».

The first word to consider is ampyx (ó $\mu \pi v \xi$, headband) (Daremberg, Saglio, 187: 251-252). This is an ambivalent term that can be used in relation either to an element of female hairstyle (something similar to a diadem) or to a combination of headgear and decoration for a horse's head. Daremberg and Saglio found an explanation for the use of this word in connection to horse trapping starting from some representations of metallic plaques placed widthways on horse's forehead (Daremberg, Saglio, 1887: 251, fig. 298). The word capistrum (kapistrion -

\footnotetext{
1 From Marchant E. C., Bowersock G. W. (ed.), Xenophon, VII. Scripta minora, The Loeb Classical Library. London - Cambridge, MA. First printed 1925, reprinted 1971.
} 


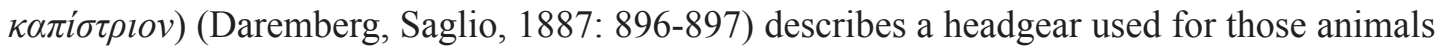
that needed to be led. Normally it consists of some simple ties with strings wrapped around the snout or the head. Daremberg and Saglio (1887: 897) proposed that this word could indicate a muzzle as well as a small basket similarly used to bridle the mouth of the horse. An example is shown at the Louvre Museum that illustrates a muzzle (Daremberg, Saglio, 1887: 897, fig. 1142). The idea, rather than word, of frenum (Daremberg, Saglio, 1887: 1334-1341), refers to a group of elements for the head and the conduction (bridles, bits, harness, etc.) of any harness, riding or working animal. The frenum is integrated by means of other items related to horse

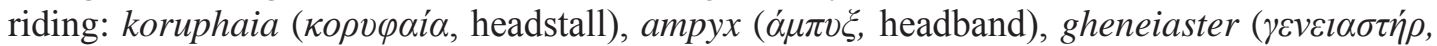

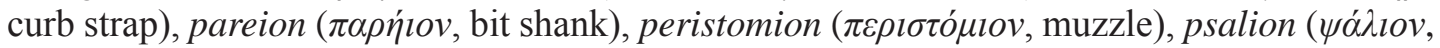
headpiece), actual bits and bossed cheek pieces (phalara - $\varphi \alpha \dot{\lambda} \alpha \rho \alpha$ ). The width of meanings assumed by this term is a sensible obstacle to its consideration as a definition for the muzzles here examined. Finally, the word frontale (prometopidion - $\left.\pi \rho \rho_{\varepsilon} \tau \omega \pi i \delta i o v\right)$ (Daremberg, Saglio, 1887: 1342-1343) corresponds to an element of horse harness that is different from the concept of the halter and can be understood rather as a «cover for the forehead», normally longitudinal, called $\pi \rho \rho \mu \tau \omega \pi i \delta i o v$.

After having presented the ancient terminology employed for the headgear, we can see how the concept of muzzle can be related to the term capistrum, which refers exclusively to the object that wraps the mouth and the nostril of the animal, while the other words define single elements and give the impression of referring to associations of objects considered functionally inseparable.

\subsection{EVIDENCE OF MUZZLES REALIZED WITH PERISHABLE MATERIALS}

Non-metallic muzzles are variously but not uniformly known through iconographical representations. Their origin is ancient and can be traced back to the $3^{\text {rd }}$ millennium B.C., where it is encountered as a fastening device under the chin made from esparto grass, leads or plaiting wickers. It was found that some onagers were represented in drawing of chariots on the socalled Standard of Ur (Littauer, Crouwell, 1979: fig. 3).

After the Sumerian tack system, in Greek regions people adopted a different model formed by a sort of small plaited bowl that wrapped completely the snout of the animal and ended with a kind of straight extremity above the mouth (fig. 1). It is hard to understand this element because of the exclusive representation of its outline, so that it could even be a disc. Several longitudinal and transversal strings seem to form this object (maybe the model mentioned by Xenophon). Depictions of these exemplars can be found only on attic vases (Daremberg, Saglio, 1887: fig. 1140) (fig. 2). We just point out a black figured hydria from Orvieto - Crocefisso del Tufo (Museo «Claudio Faina», inv. N. 2674), dated around 550-540 B.C. (Fiorini, 2006: 230-231; $A B V, 140.4)$. A very similar hydria, held by the National Archaeological Museum of Madrid (inv. N. 10920), is attributed to the Priamus Painter and dated at the 520-510 B.C. It shows the old king getting on a chariot drawn by four horses; a young man is tying them to the chariot, and two horses wear this type of muzzle (Beazley, ABV: 332; Cabrera, 2005: 148-149) (fig. 3).

It is difficult to know if the use of this Greek model had been abandoned during the Antiquity on behalf of other solutions, or if it just did not recall the attention of later artists. The representation of muzzles is very rare on italic vases and in some cases the halter includes even the muzzle. They occur by scenes of heroic celebration connected to military deeds or to gods of warfare. An example indicated in a pelike of the Policoro Painter from the necropolis of 


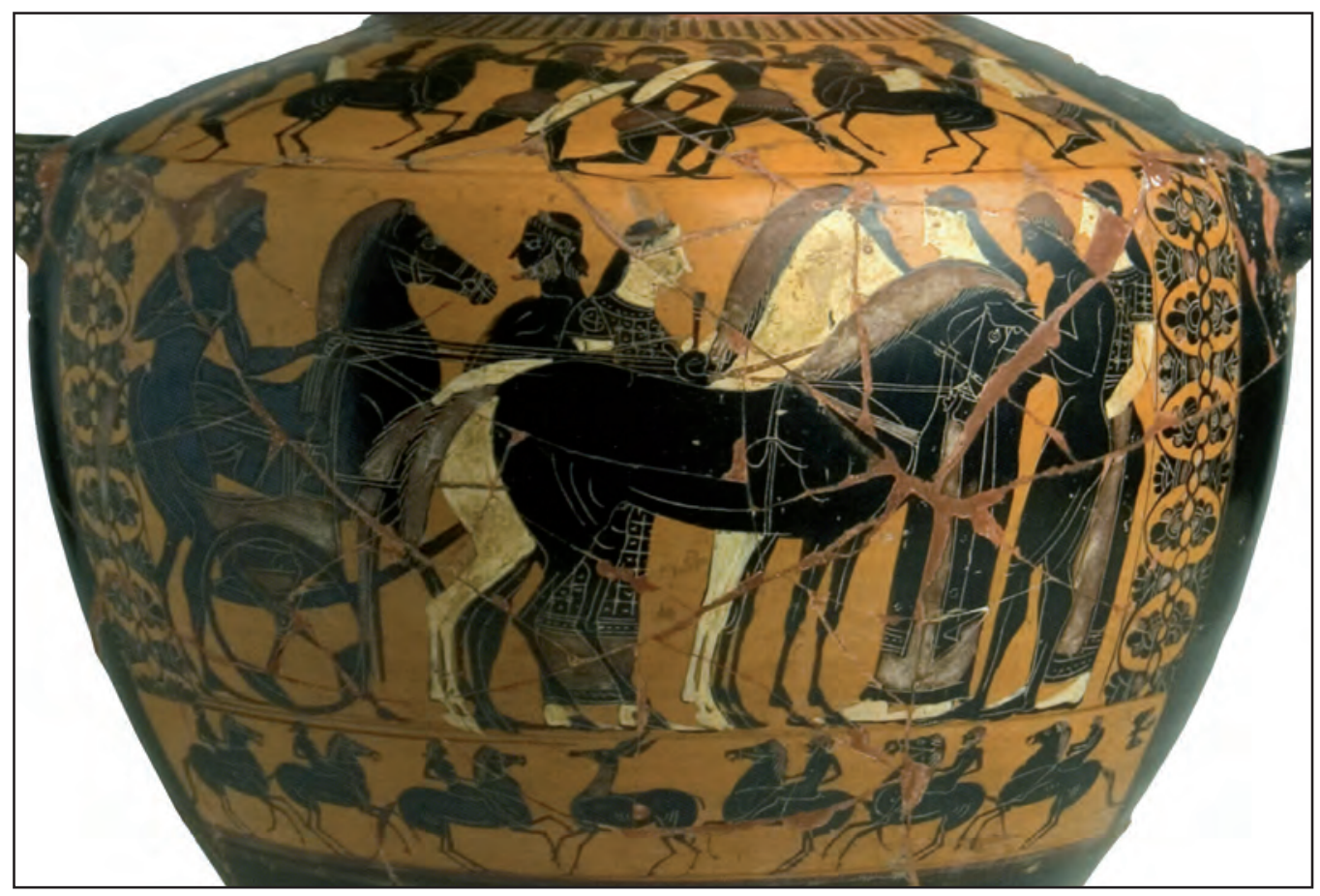

Figure 1. Greek muzzles realized with perishable materials on attic vases: Orvieto-Crocefisso del Tufo, 550-540 a.C. (Fiorini, 2006: 230-231).

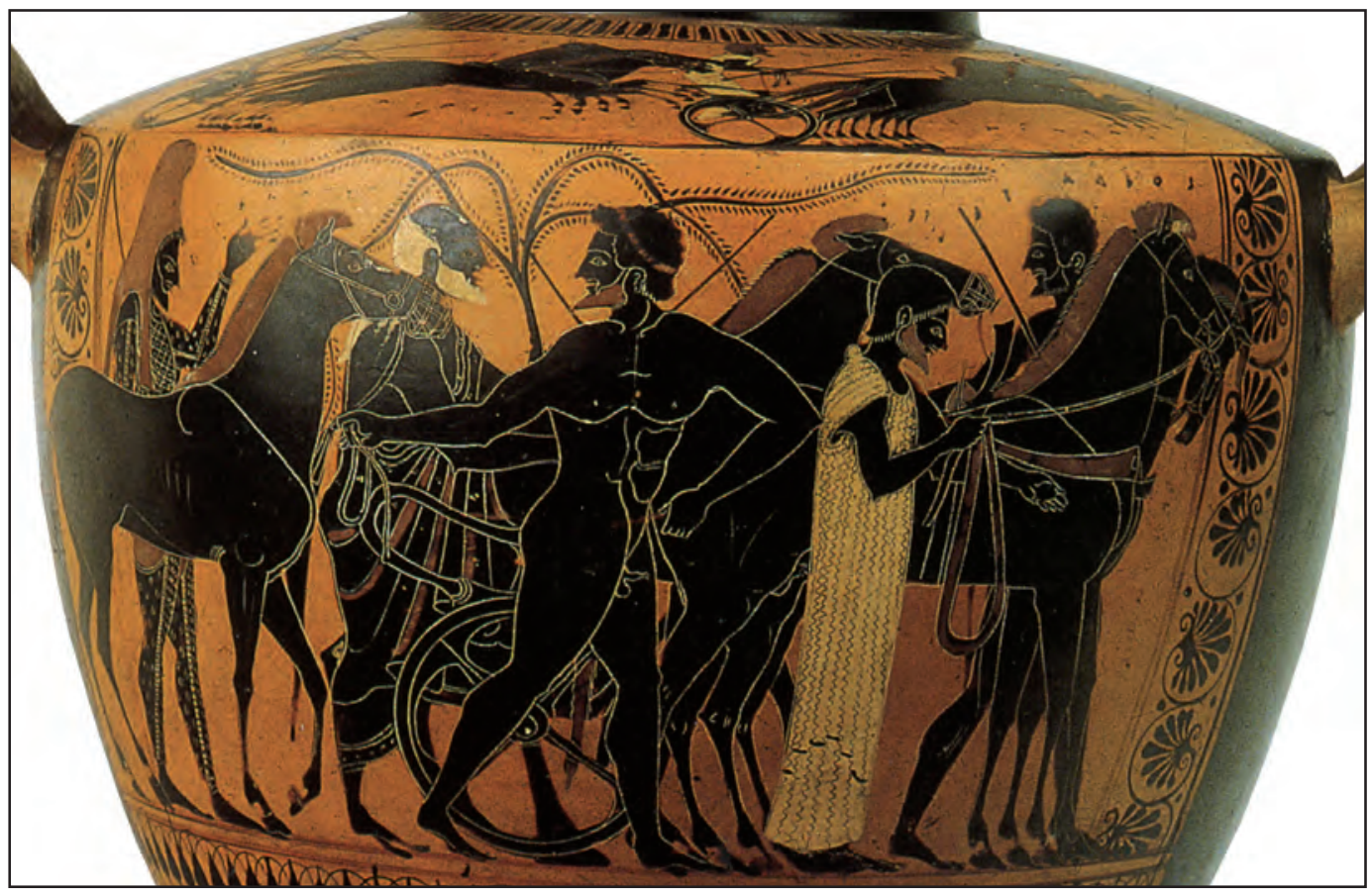

Figure 2. Greek muzzles realized with perishable materials on attic vases: Museo Arqueológico Nacional de Madrid, 520-510 a.C. (Cabrera, 2005: 148-149). 


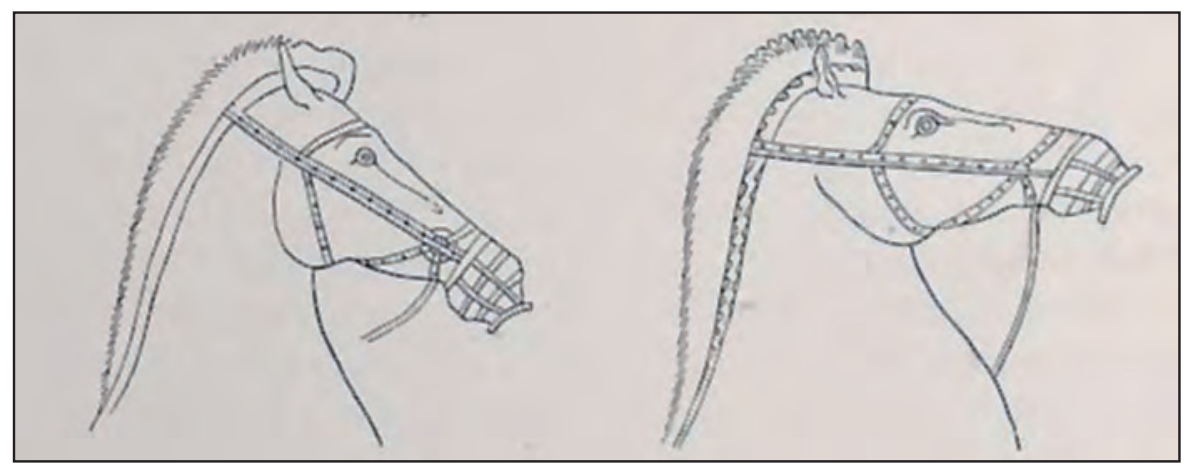

Figure 3. Greek muzzles realized with perishable materials on attic vases (Daremberg, Saglio 1887; Pernice, 1896).

Policoro-Heraklea (National Archaeological Museum of Siritide, inv. N. 35304) (fig. 4), where on the A side a pair of horse riders are painted (identified as Hermes and Poseidon), both with weapons and riding their horses. On the B side Athena guides a biga, and a third one is ridden by a female charioteer. The horses of both sides show metallic muzzles that are rhombusshaped (Bottini, 1994: 151-152). Otherwise, this low attention for halters, prometopidia and muzzles encounters many analogies in the representations of other Italic specimens, like belts, painted exclusively by artists of southern Italy (Bottini, 194: 152). Only considerably later,

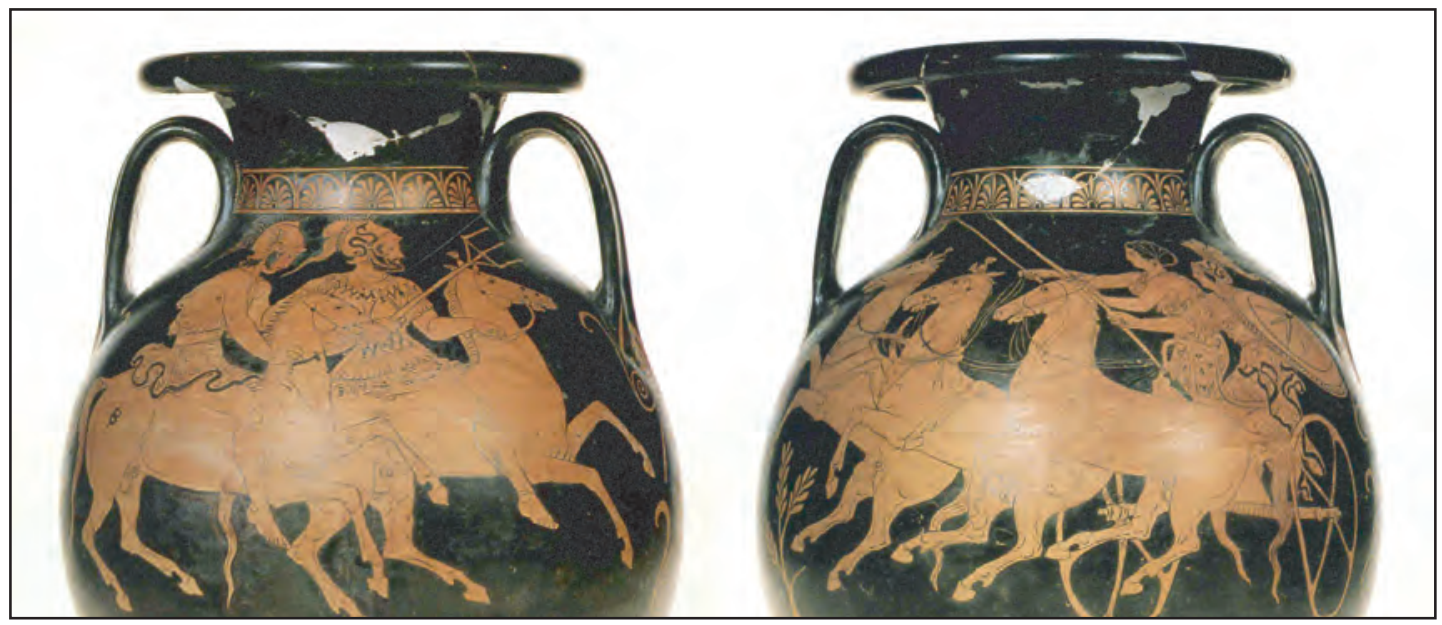

Figure 4. Metallic rhomboidal muzzles: Pelike of the Policoro Painter (from necropolis of PolicoroHeraklea). A: Hermes and Poseidon as horsemen; Cara B: biga with a third horse, with auriga and Athena (Bottini, 1994: 151-152).

although with some modifications, can a representation of a muzzle on a late Roman monument be found, the Column of Theodosius (Daremberg, Saglio, 1887: fig. 1141). Nevertheless, it has to be said that this exemplar shows a different structure, because it recalls a kind of basket realized by means of plaiting flat and wide stripes, unlike the small Attic basket, which is composed by fastened sticks. 


\subsection{THE BRONZE MUZZLE AND ITS ORIGINS}

The metallic muzzle may have been invented in the central and northern regions of Greece, where a long military equestrian tradition and the social praise of horsemen were synergic. In addition it can be said that the most ancient exemplars seem to translate the principle of the small baskets noticed in the Attic depictions into bronze. This form would have been later developed with a rich accessory decoration. There are ancient references to metallic pieces associated to horse's heads, at least in the first half of the $5^{\text {th }}$ century B.C., when Aeschylus writes this colourful image in his Seven against Thebes: «his mares, in eagerness to fall at once upon the gate, chafe in their frontlet-bands as he wheels them to and fro; their muzzlegear, filled with the breath of their proud nostrils» ${ }^{2}$ (Aesch., Sep., 461-464). It is, evidently, a very complex quotation, which does not necessarily refer to a metallic muzzle. The word used by Aeschylus, phimos ( ment described. Some translators have supposed that the muzzle could have been possibly realized by means of metallic tubes connected to the horse's snout, relying on the opinions of late Greek commentators. Anyways, it seems that Greeks of the classical period had noticed the importance of bronze associated to the horse in order to frighten the enemy, both visually, due to its shining, and acoustically, as amplification of the whinny. Moreover, apart from its military employ, bronze has to be considered a peculiar means to exhibit the power of a horseman. Finally, a muzzle could turn a negative characteristic of the horse into a positive device, determining thus a selective production of an object which before had been made out of very poor materials. Particular significance would have had later some decorative elements for horses that came up ex novo in southern Italy (Peucetia, Apulia and Lucania), starting from the $5^{\text {th }}$ century B.C. They consisted of ornamental parts covering the head, prometopidia, and pectorals, prostenidia. These objects have been found together with prestigious military panoplies inside remarkable tombs (LoPorto, 1996), including some princely ones. The best documented case is the one of the tomb from Sangiorgio di Ginosa (LoPorto, 1996: 24-33), with a pair of bronze horse's prometopidia associated to a pair of horse's prostenidia (Lippolis, 1995: tab. LXXXII, 2; LoPorto, 1996: fig. 25, 3-4). Another pair of prometopidia from Ruvo is split between Karlsruhe and the National Archaeological Museum of Naples (LoPorto, 1996: 30); two more are in the Museum of Basilea (Bottini, 1989: 706); another comes from a tomb in Sangiorgio di Lucania, now kept in the Museo Provinciale of Potenza (Bottini, 1989: 706); one from the tomb 669 of Lavello; three more exemplars from the Monterisi-Rossignoli hypogeum of Canosa (Bottini, 1989: 706); one, belonging to the White and Levy collection, supposedly from a tomb of Ruvo di Puglia (Von Bothmer, 1990); one from the J. P. Getty Museum in Malibu (Born, Hansen, 1994: Abb. 108). Another example, is a slightly older than the previous items, are a pair of bronze laminas of Peloponnesian production in form of bovine head, found inside a barrow in Castiglione di Conversano (Puglia, Italy), whose chronology is fixed to the first half of the $6^{\text {th }}$ century B.C. The grave goods of a tomba principesca rinvenuta su Corso Cotugno (già Via dei Cappuccini) in Ruvo di Puglia (Montanaro, 207: 440-488, n. 103) include two pair of prometopidia and three prostenidia, and can be dated to the last quarter of the $6^{\text {th }}$ century B.C. Other two bronze pectoral laminas, similar to the ones from Ruvo, are kept in the Museum of Naples (LoPorto, 1996: 30). Finally, other two tombs of Ruvo di Puglia located in Corso Cotugno (già Via dei Capuccini): they are the numbers 114-115 of Montanaro (2007: 537-546), respectively with a prostenidion and a pair of prostenidia, dated to the $5^{\text {th }}$ century.

2 From Aeschylus, I. Suppliant Maidens - Persians - Prometheus - Seven against Thebes. Translated by Herbert Weir Smith. Loeb Classical Library. London - Cambridge, MA, 1963. 
Last but not least, a prometopidion from Olympia (Archaeological Museum of Olympia, inv. N. B.4800). All these elements are considered of South-italic production, maybe from Taranto (Bottini, 1989: 710). Looking to these objects it can be noticed a remarkable development of decorations that led to a greater technological complexity, combined with openwork decorations of bronze muzzles starting from the $4^{\text {th }}$ century B.C. In this sense, the Apulian grave from Ruvo di Puglia, today part of the White and Levy collection at the Metropolitan Museum, New York, is of particular significance (Von Bothmer, 1990: 114-122).

To understand the importance and the singularity of horse decorations is the consideration of votive offerings made by important people in several sanctuaries. If we examine together muzzles, prometopidia, harness and phalerae, it can be noticed how horse headgears were employed by eminent offerers as semata of their military divisions, which indicates even a privileged status among their society. One reference, made in a dedication of the $1^{\text {st }}$ century B.C. by the winner of the games in honour of the Isthmian Poseidon, is about a muzzle that closed the horse's snout (Anderson, 1961: 43, n. 7; Palatine Anthology VI, 233.I). Another reference is an epigram for the king Magas of Cirene (Chamoux, 1958), that is described as a votive offering of a shield and equine harness by a certain Eupolemos; another case, maybe the most exaggerated, is the offering, made by Ptolemy I, of 20 prometopidia in the sanctuary of Athena Lidia (I.Lindos 2 = FGrHist IIIB, 532C, 1. 111-113; Hazzard, 1992: 55). Apart from the written evidences, the objects found in sanctuaries are conspicuous. Here follows a selection: a muzzle from the Vigna Nuova sanctuary in Crotone (LaGernière, 1997); a prometopidion, decorated with a hoplite's head (known even among the groups from the necropolis of Ruvo di Puglia), offered in the sanctuary of Olympia during the second half of the $6^{\text {th }}$ century B.C. (Archaeologial Museum of Olympia, inv. N. B.4800) (Rolley, 1983: 237, cat. n. 272); the prostenidion from Samos (Museum Vathy, inv. N. B.2518; Olmos, 2000: 228), with a representation of the fight between Herakles and Geryon, dated to the last quarter of the $7^{\text {th }}$ century B.C.; the prometopidia with Aramaic inscriptions from the Heraion of Samos (one item) and from the Apollo temple of Eretria (two items) (Charbonnet, 1986; Kyrieleis, Rölig, 1988; Fales, 2006). The exemplar from Samos was made around the end of the $9^{\text {th }}$ century and donated in the sanctuary about in 600 B.C., whereas one of the exemplars from Eretria, indicates that is in fact a part of the same pair, approximately dated around the middle of $8^{\text {th }}$ century B.C. (Burkert, 1991: 70). In the inscriptions of both objects occurs the name of the ancient owner, Hazael, king of Damascus. These offerings, parts of loots or simply votive objects, show the singularity, the importance and the also well known long tradition of connection between aristocracy and horsemanship.

\subsection{The StUdy of Peninsular muzZles: history and PROBlems}

At the end of the $19^{\text {th }}$ century E. Pernice published a study about horse tacking elements that listed several bronze muzzles of Greek typology, as anticipated by the title of the volume (Pernice, 1896). Pernice's work provided a catalogue of all the exemplars known at that time, though spread over different museums, with a chronological arrangement based on archaeological contexts (if known) as well as, especially, on vase paintings. This chronological setting established a range from the $5^{\text {th }}$ to the $3^{\text {rd }}$ B.C. One of the muzzles, apparently found in the grave of a horseman in Boeotia, caught the attention of other scholars (Anderson, 1961: fig. 36a; Vigneron, 1968: fig. 28e; Taylor, 1975: 130, fig. 12) (fig. 5). Some objects found in the same tomb were used for a dating to the $4^{\text {th }}$ century (Anderson, 1961; Vigneron, 1968: 76-77), though later reviews suggested a higher chronology on the basis of some metallic objects: a bit 
with curved shanks and some ring-shaped buttons with small roses, which were considered more ancient by $\mathrm{W}$. H. Gross (quoted by Schüle, 1969: 126), who doubted that they could have been made after 490 B.C., whereas a earlier date, which would have theoretically matched better with some bronze bits from the same deposition, could not be refused (Schüle, 1969: 126). These suggestions ingenerated a misunderstanding of Pernice's initial chronology $\left(5^{\text {th }}\right.$ $-3^{\text {rd }}$ century), since the German scholar had established a chronological range due to the

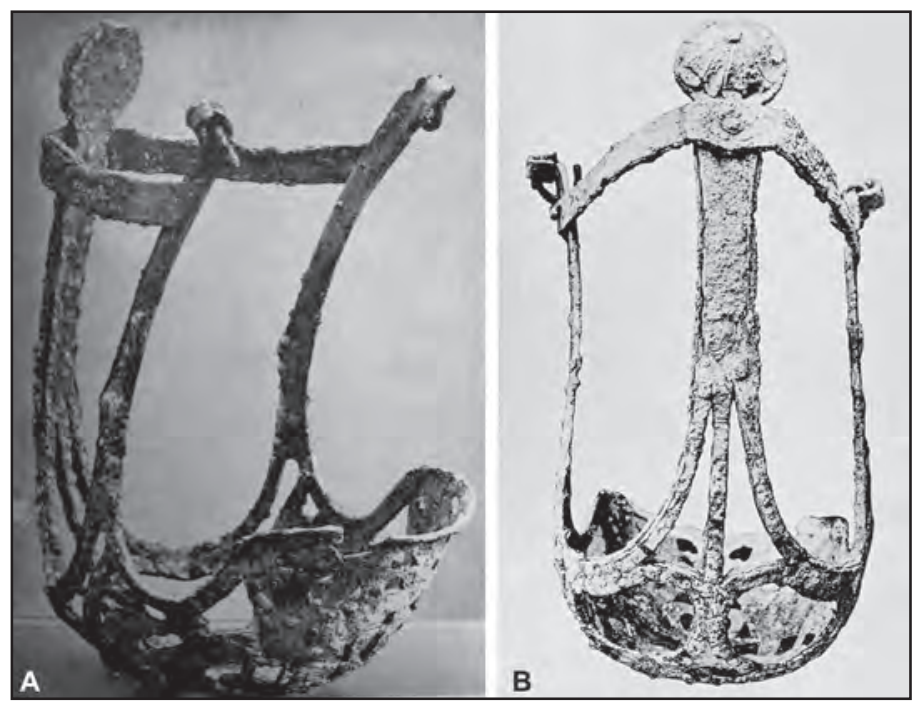

Figure 5. Muzzle from Beotia: A. (Anderson 1961: 56, n. 9); B. (Pernice, 1896: taf.1). sources used by him. Firstly, he analyzed painted pottery, where there is no distinction between metallic and perishable muzzles. Secondly, he considered halters and muzzles together by indicating them with the same word - Maulkorb. The above-mentioned scholars (Anderson, Vinegron, Gross and Schüle) were trying to date this objects earlier and they thought that the dating could be proved by the presence of bronze bits. The comparison with

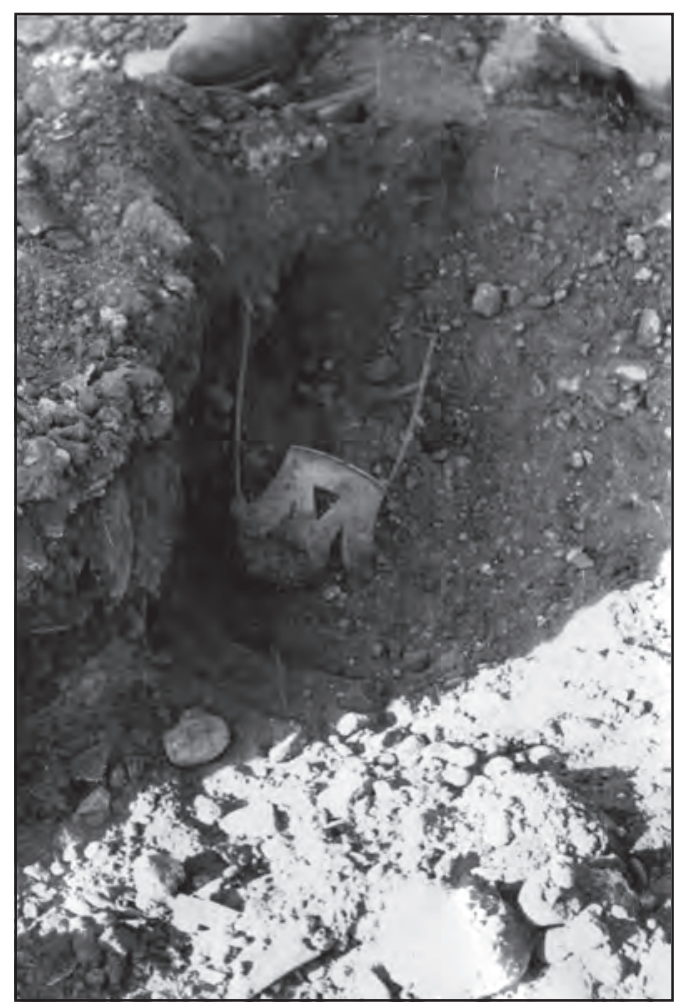
Italic bronze bits, especially the Villanovian ones, dated back to the $8^{\text {th }}$ and the $9^{\text {th }}$ centuries, gave as result an apparent similarity between the Boeotian exemplar and these ones. Nevertheless, proceeding from a correct classification and description of both bits typologies one can notice considerable differences and a consequent change in the chronology. We believe therefore that it is important to reconsider here the dating of the Boeotian bit, since it has been a source of debate concerning the dating of muzzles. First of all, the extremities of the hooks attached to bit shanks show a tripartite decoration with a globular termination, separation discs and a spindle-shaped element. This type of decorations occurs especially on the tips of situla's handles of the $5^{\text {th }}$ century, lasting subsequently till the Roman period. Furthermore, the hooks are connected to the bit through a conic-shaped button termination

Figure 6. Muzzle n. 1 from La Pedrera (Térmens, Lleida) at the discovery moment (Photo: Servei d'Audiovisuals de l'IEI, Lleida). 
of the mouthpiece, which passes through the centre of the shank. This kind of connection does not exist until the $4^{\text {th }}$ century B.C. Finally, the mouthpiece seems to be articulated in two parts, each of them showing four lines of spiked knobs that end with a disc. A dating back to the $4^{\text {th }}$ century has been proposed for this typology (Donder, 1980).

A new exemplar of muzzle with geometric decoration has been discovered in 1958 in the Ilergetan necropolis of La Pedrera (Térmens, Lleida) (fig. 6). W. Schüle, who has been the first to study the muzzle, proposed an earlier chronology than the one of the controversial Boeotic exemplar (Schüle, 1969: 44, fig. 181.1), dating it at the beginning of the $6^{\text {th }}$ century in consideration of the association with an iron bit; this dating has been generally accepted until recently (Plens, 1986: 191; Garcés, 2002b: 198-199). Despite that, the dating of the abovementioned bits has been lately updated and corrected on the basis of a comparison with Celtic bits, the mouthpiece's articulation and the decorations of the latter being a distinctive element for a dating to the $4^{\text {th }}$ century (Graells, 2009; in press, 2011). In W. Schüle's interpretation of these objects a Greek origin was rejected in favour of a Cimmerian-Pontic one, in spite of the evidence that openwork metallic muzzles were not known among Scythians (Schüle, 1969: 129), even though horsemanship was considered as a basic part of their society and lifestyles. Now we are able to propose a distinct origin between southern Italy and continental Greece and a peculiar transfer of muzzles from this region to the Ilergetan area (Graells, 2009; in press, 2011).

\section{THE TERMINOLOGY OF STRUCTURAL ELEMENTS}

Muzzles are formed by various elements that allow us to classify them and simplify both their description and comparison. Considering the lack of terminology to describe ancient muzzles we propose a group of specific words in order to provide a universal definition, similar to those that have been made for other archaeological objects - i.e. weapons (Quesada, 1997) and equipment for horse tack (Quesada, 2005).

A muzzle can be divided into six functional parts, whose presence or absence and whose peculiar characteristics constitute the basic elements that we can use to set a typology. Each of the six parts also respectively shows different elements that define the morphological aspect and the decoration of every muzzle.

\subsection{BOWL GUARD}

It is the closed lower part of the muzzle that protects the nostril and the mouth. In order to let the horse breathe it has some openwork holes. This can be surrounded with geometric or floral decorations, to be possibly linked to a chronological evolution. The presence of a decoration in the frontal part of the bowl guard is called central pattern.

\subsection{CHINPIECE}

It is the internal flexed portion of the bowl guard and is located under the horse's lower jaw, thus allowing a correct working of the muzzle. On those openwork muzzles where the bowl guard is missing, it can correspond to two parts: a bar joined by means of lateral tensors that prevent the horse from opening his mouth or a free lower bar that allows the opening of 
the mouth. On closed muzzles it is the lower extremity of the lamina and permit to extend the decoration of the bowl guard.

\subsection{ARMS}

These are elongated elements that extend the bowl guard or the chinpiece, connecting them to the bridge. The arms are parallel bars with rectangular section and a tip called twisted fixing point, which can be either rolled up to serve as a fixing element, or scroll-shaped, with a duck-head as tip. Normally, a ring can be found connected to this point, in order to fasten leather strips or similar ones that contribute to fix the halter to the head of the horse. At the opposite extremity the arm ends with a rhombus-shaped enlargement, which we will call distal rhombus. It is located by the inflection point of the nostril. Finally, the arm marks the side limit of the muzzle's eye, being the upper limit the so-called frontal bar.

\subsection{FrontAL BAR}

The frontal bar is an elongated element, parallel to the arms and placed between them, enforcing the joint structure. Similarly to the arms, it connects the bowl guard to the bridge. Openwork muzzles do not own this element.

\subsection{BRIDGE}

This is the structure that connects the tips of the arms through two tensors, nearby the twisted fixing point. The tensors are normally joined to the arms by means of a rivet threaded into the so-called proximal hole. On openwork muzzles it has the shape of a curved sheet, which can be variously decorated.

\subsection{FRONTLET}

The frontlet, or decorative knob, is placed in the middle of the forehead, above the connection between the frontal bar and the bridge - or immediately above the muzzle. It can have various shapes that can be restricted to two main groups: circular elements and rectangular elements.

\section{TYPOLOGY}

The practical act of shutting a horse's snout is simple and can be reduced to a limited number of possibilities: 1) by wrapping the snout with a small basket or a cap; 2) by closing the mouth through a wide strip along the axial direction of the head; 3 ) by closing the mouth in the transversal direction. This third solution is still used in modern riding systems and can be found on metallic muzzles, where it corresponds to the part installed under the chinpiece. From the first possibility derive metallic muzzles with bowl guard that can be opened to let the horse breathe. 


\subsection{TYPE 1}

Its structure is determined by a final bowl guard, with a variable openwork decoration, although it can be quite massive, as the case of the Louvre exemplar - but always with some kind of perforation. The bowl guard is held by three parallel strips (as a prolongation of the basis), tied on the upper part to other two small transversal strips, nailed at the extremity. These end with two small rings, whose function is to allow to put on and to pull off the equipment whenever needed. An ornamental effect can even be obtained thanks to the shining of the metal, as well as to the light plays of the openwork decoration and the frontlet.

Openwork muzzles, independently from the width of the openings, remember for their concept the first prototypes made of leather and esparto grass. Those ones, in fact, were bended around the snout like small baskets and were tied by means of strips on the upper part of the head of big domestic animals to prevent them from eating or biting.

The type 1 is distinguished by the presence, on the lower part, of a closed bowl guard with an openwork decoration forming different patterns, one for each exemplar. This bowl guard is likely to substitute the wicker basket painted on several Attic black figure vases. The other structural elements allow us to distinguish between two subgroups:

\section{Subtype 1.A (fig. 7)}

The frontal bar does not show any decoration, the arms have rhombus-formed patterns nearby the bowl guard and end above in a rolled up twisted fixing point that allows the insertion of a ring; it has a frontlet consisting of a circular element and the tensors form a light curve, ending with a crushed surface on which has been made the proximal hole in order to connect the tensor to the arm. Only the exemplar of the Carapanos collection (Pernice, 1896: pl. 1) (fig. 8) show us another version of this model, namely a single tensor that joins the two arms and is connected to the frontal bar through a rivet located under the circular frontlet; it could be the result of a substitution of the original tensors, in case of a damage, or it can suggest a variation in the fabrication.

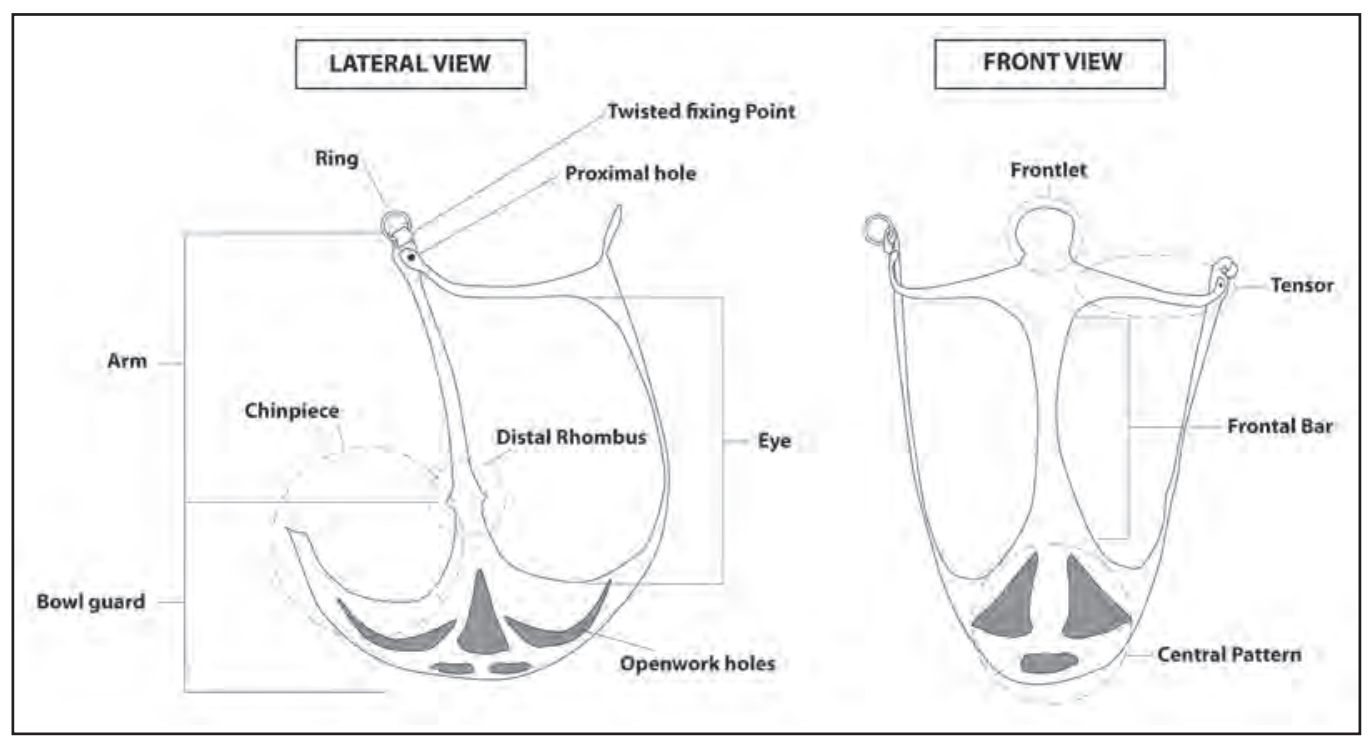

Figure 7. Structural scheme of type 1.A muzzles. 


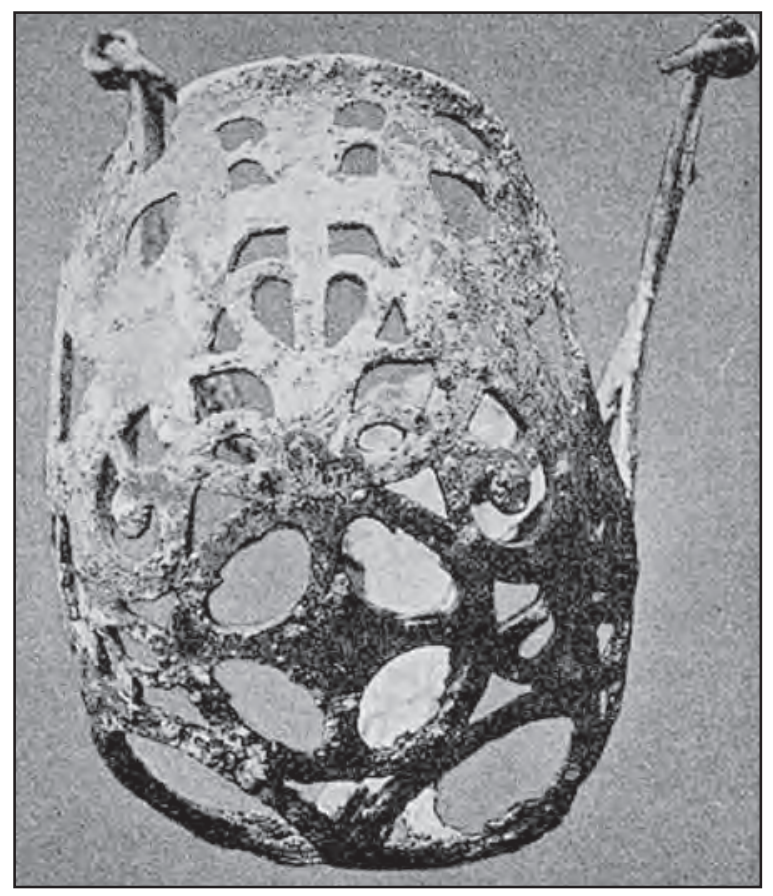

Figure 8. Muzzle of Carapanos Coll. (Pernice, 1896: 7).
Subtype 1.B (fig. 9)

The frontal bar has a decoration on its central point. This decoration can consist either of floral and geometrical elements, which can be carved directly on the surface of the muzzle, or with figurative applications, as the case of a Silenus on a muzzle at the Metropolitan Museum of Art in New York (fig. 10). The surfaces of arms, tensors and frontlet show carved lines that define the eyes, as well as openwork patterns. The arms are embellished with a decoration formed by floral and geometrical elements that substitute the rhombusshaped patterns already seen on the type above. Concerning the arms, they have a duck-head shaped termination, rolled on itself, where it is possible to fix a small ring. The frontlet is a lamina decorated with a combination of openwork, carving and appliqués,

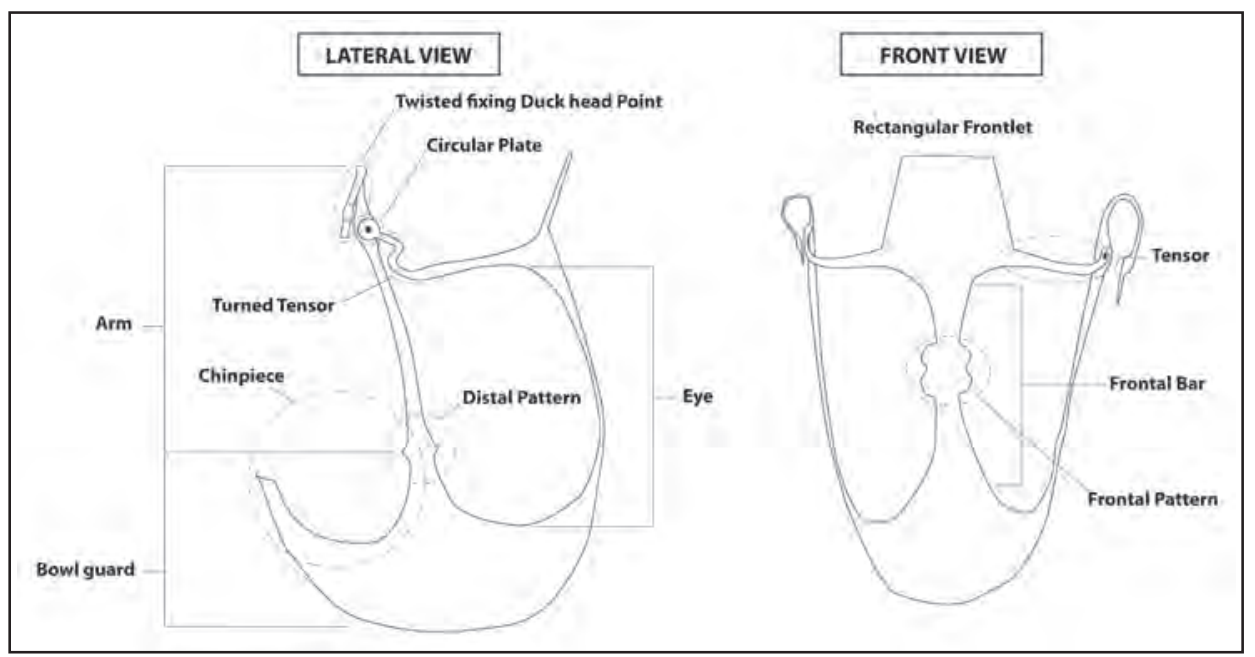

Figure 9. Structural scheme of type 1.B muzzles.

showing a range of shapes that goes from rectangle to trapezium. The tips of the tensors are twisted and form an «S»; they are connected to the arms through a joining hole.

The study of ancient horse muzzles starts with the work of E. Pernice, who considered them a Greek production. Subsequent finds have permitted to refine this statement and to propose a significant concentration area located between the Messapian region, the Apulian region (the current Puglia, in Italy) and Macedonia, even though some exemplars have been 


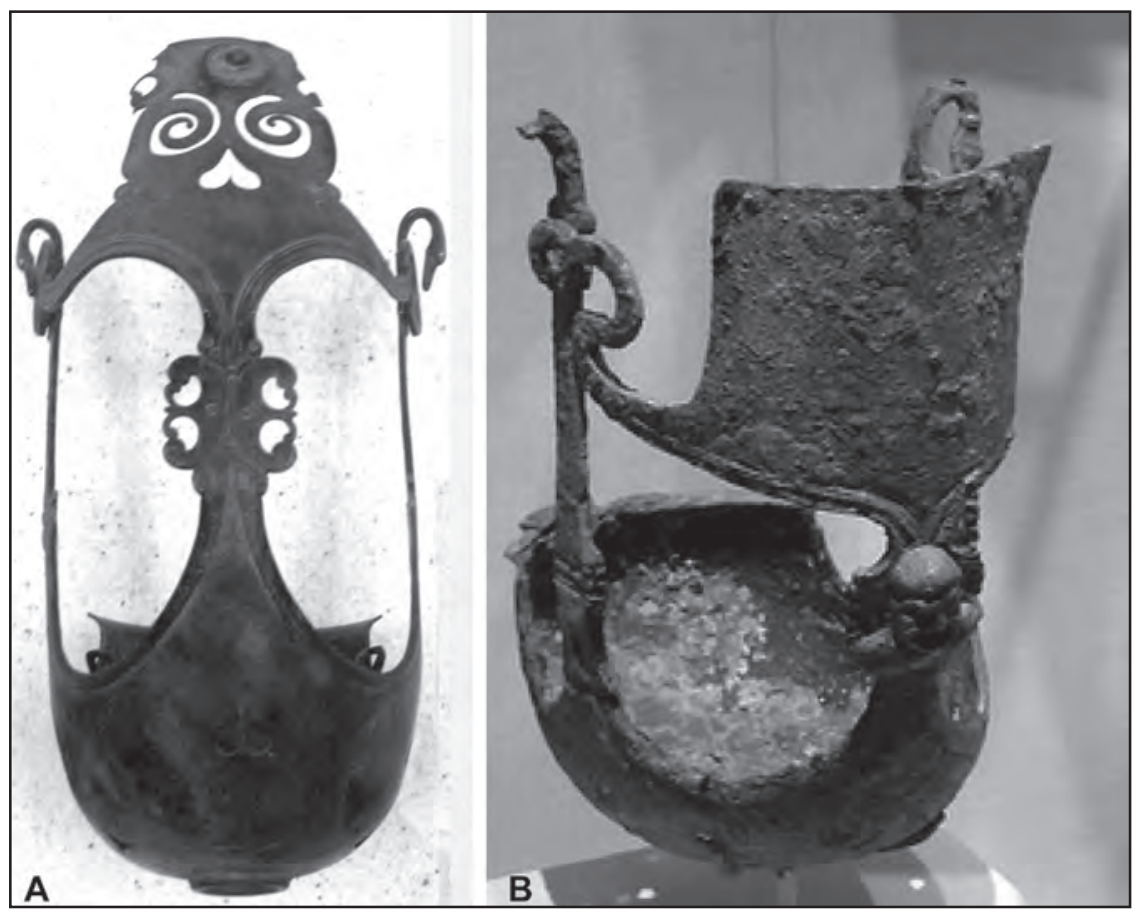

Figure 10. Muzzles from: A. Louvre, Campana Coll. (deRidder, 1915: 26, pl. 71); B. Metropolitan Museum (Von Bothmer, 1990).

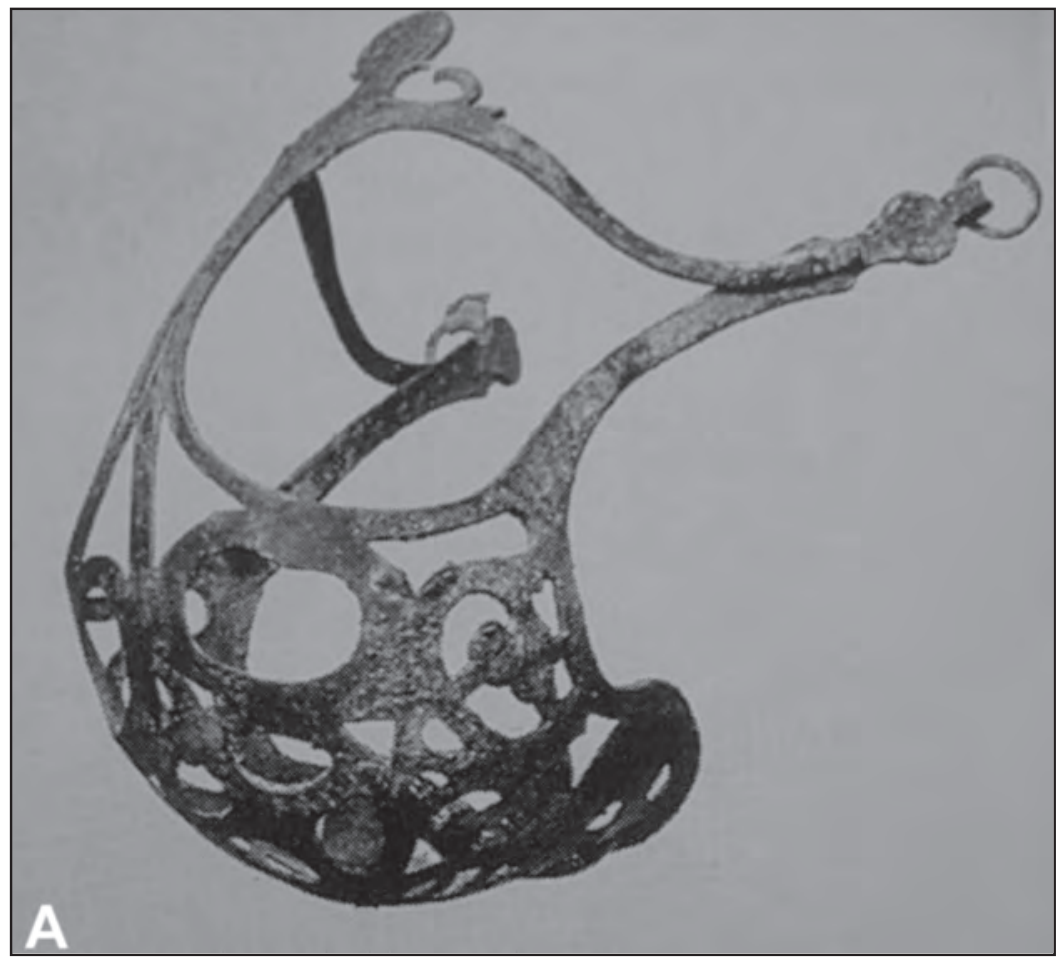

Figure 11. Muzzle from Apulia, White \& Levy Coll. (NY) (Mannino 2003: 715). 


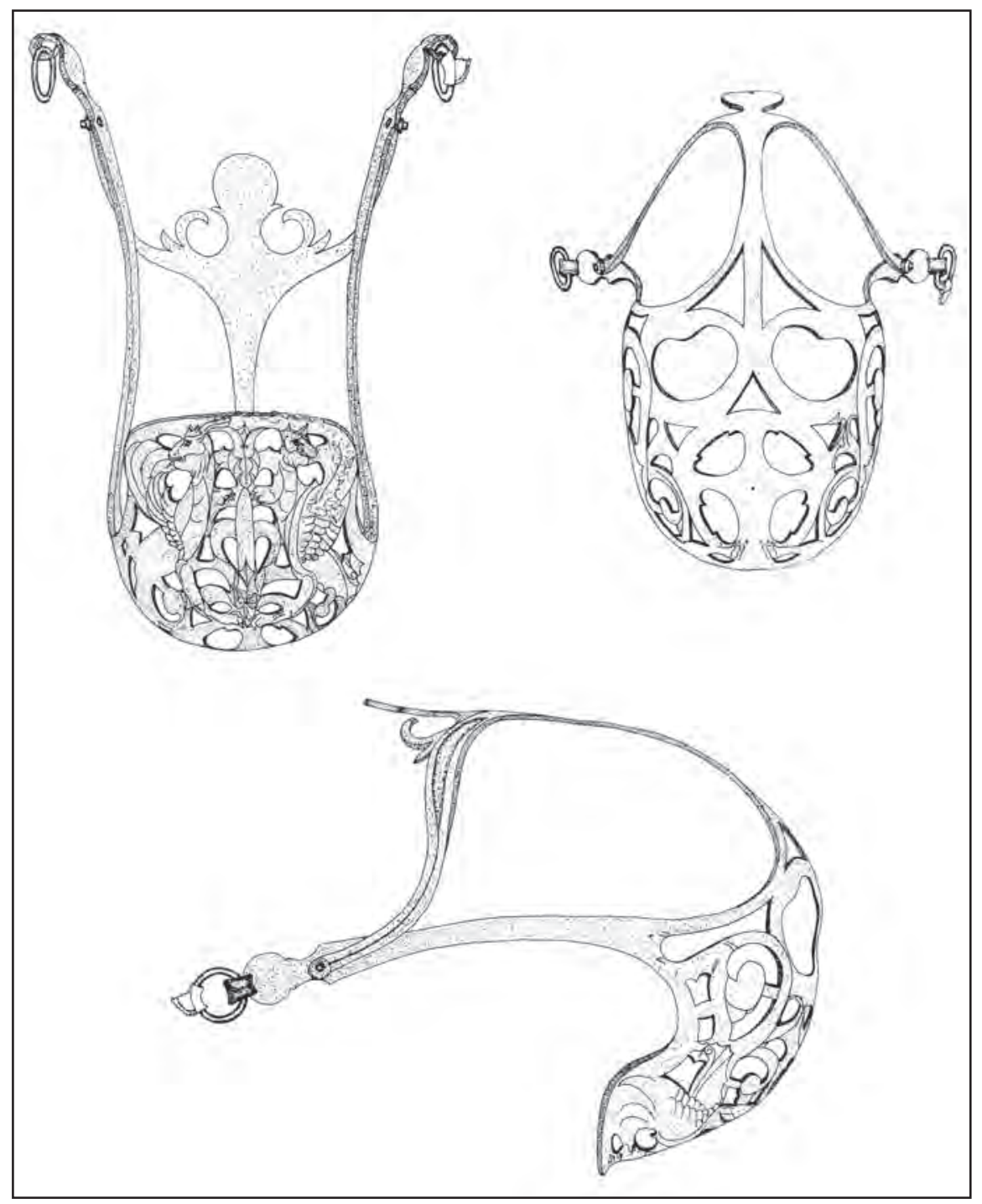

Figure 12. Muzzle from Apulia, White \& Levy Coll. (NY) (Von Bothmer, 1990: 121).

recognized in Central Greece. The chronology of these objects is based on reliable sources that are concentrated in the $4^{\text {th }}$ century B.C. The muzzle from Berlin State Museums comes from a Boeotian grave and was found, together with two bits, inside a tomb dated to the $4^{\text {th }}$ century B.C. (Anderson, 1961: 56, n. 9) (fig. 5). This one has been interpreted as a Greek muzzle on the basis of Pernice's above mentioned suggestion (fig. 8). On the other hand, a muzzle from the White-Levy collection in New York, dated around 330 B.C. (Mannino, 2003; 715), appeared from an Apulian tomb with a complete warrior's panoply (Chippindale, Gill, 2000: 498; Von Bothmer, 1990) ${ }^{3}$ (figs. 11, 12). An exemplar from the Vigna Nuova sanctuary in Crotone has to be added to this group (LaGenière, 1997: 261) (fig. 13). The muzzles in the British Museum

\footnotetext{
3 Part of the White and Levy collection. Acquisition described as a complete set of grave goods from an Apulian grave, including an Italo-Chalcidian helmet, a cuirass, two greaves, a horse frontlet and a muzzle (Chippindale, Gill, 2000: 498).
} 


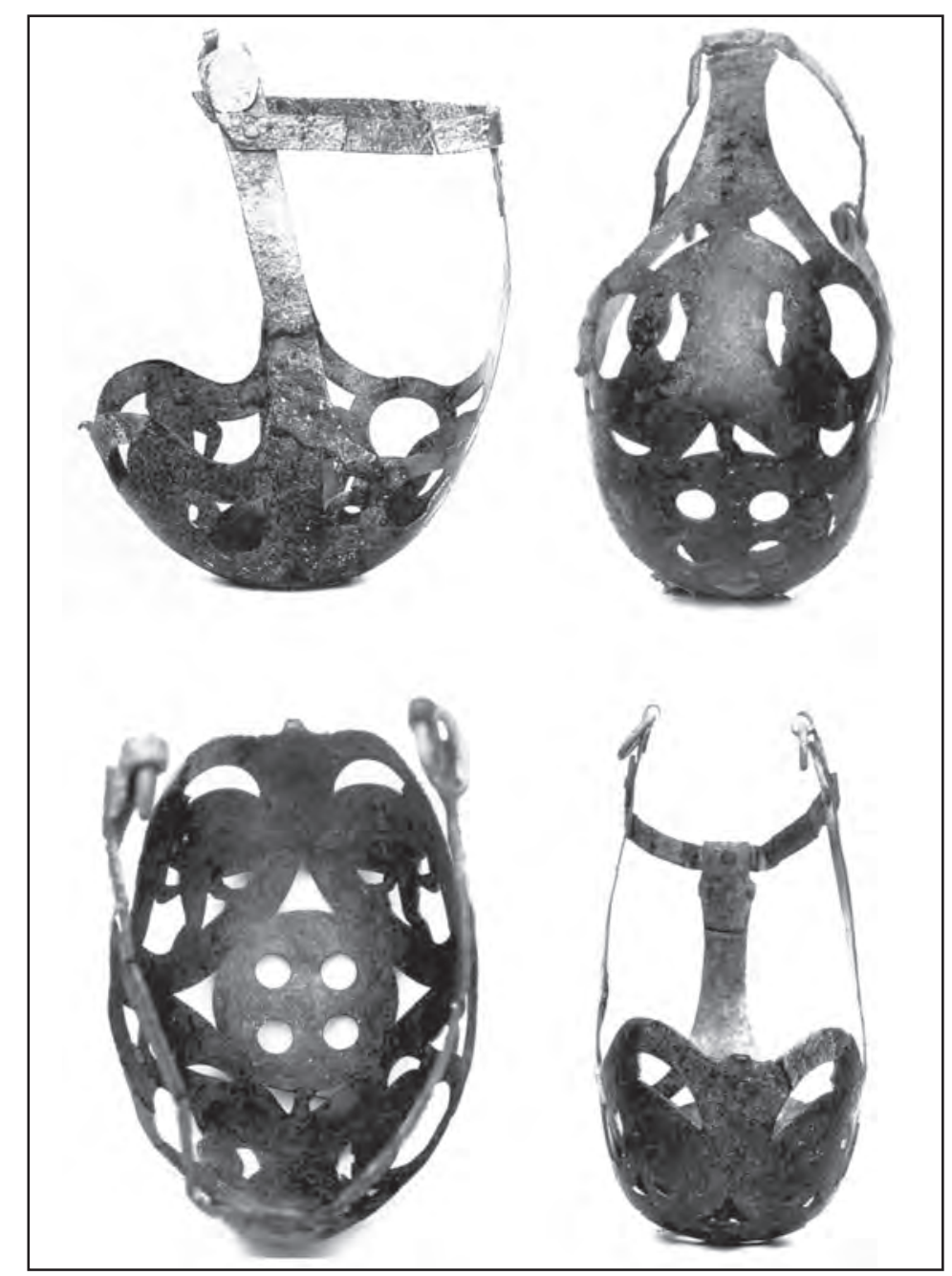

Figure 13. Muzzle from Vigna Nuova (Crotone), (LaGenière, 1997: 261).

do not have any archaeological context (N. Inv. 2877; Walter, 1899: 352)4 (fig. 14), as well as the ones in the Louvre Museum, formerly in the Campana collection (fig. 10) (N. Inv. 1517 and 1518; De Ridder, 1915: 26, pl. 71), two exemplars in the Metropolitan Museum of Art and the n. 617 in an auction catalogue of Harlan J. Berk Ltd. antiquary, Chicago (fig. 15).

The decorations of these objects show a great variety of combinations with openwork patterns: geometric or, like on the exemplars collected by E. Pernice, with floral patterns and griffins. Less frequent are decorations with openwork figures, like on the muzzle from Vigna Nuova in Crotone ${ }^{5}$, where we can see incised lines - the other ornamental technique employed.

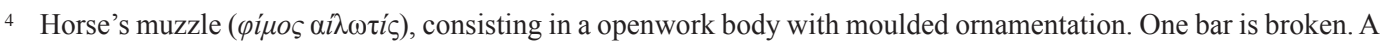
small rose decorates the central part, whereas three ivory studs ornate the upper part. Formerly part of the Castellani collection, purchased by the British Museum in 1873. To be mentioned are even the exemplars N. Inv. 2878 and 2879, from Ruvo di Puglia, though belonging to a type without openwork pattern.

5 Two combat scenes: on one side, the fight of two hoplites; on the other side, a representation of Herakles as a child with the two snakes. The Herculean scene on the halter and the fact that it has been found in Crotone have both been referred to the myth of Geryon and to his prophecy about the foundation of a city named Kroton (LaGenière, 1997: 261). 


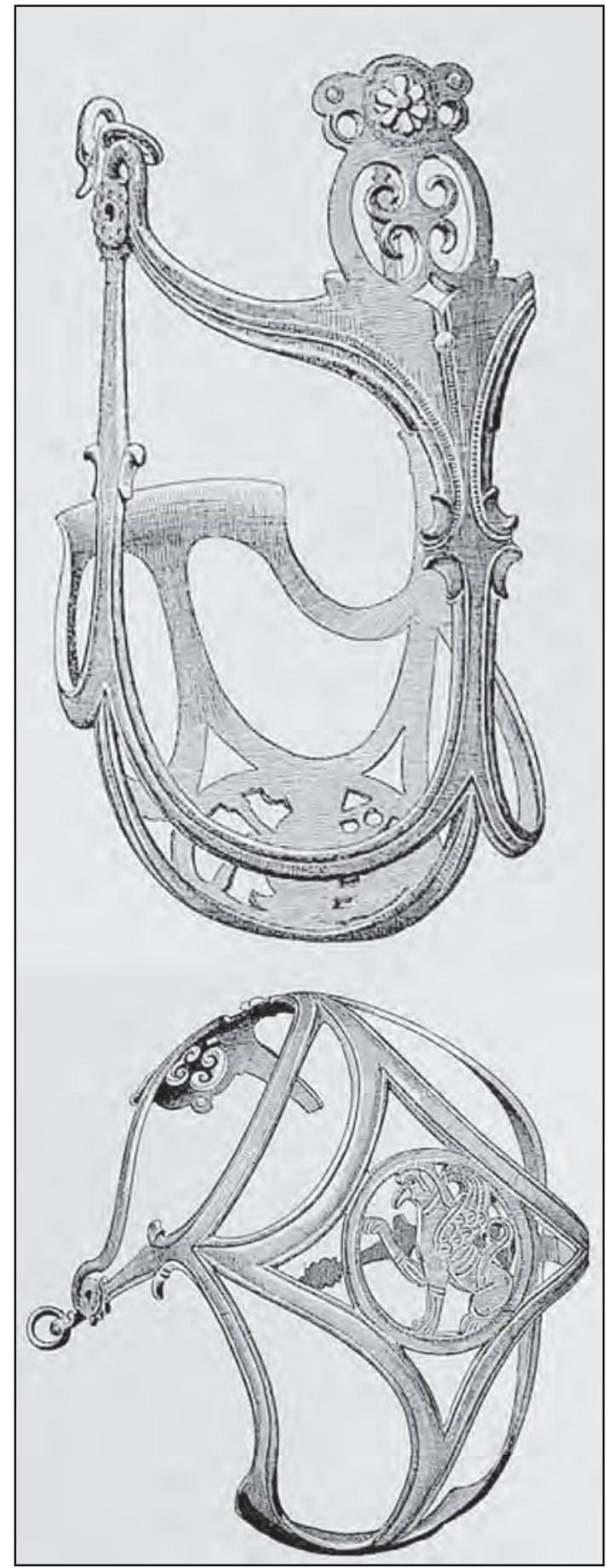

Figure 14. Muzzle from Ruvo, British Museum (Walters, 1899: 352).

Figure 15. Muzzle from Apulia, Metropolitan Museum.
Of particular interest is a bronze muzzle of this typology painted inside a grave in Makryghialos, the northern necropolis of Pydna, found in 1983 (fig. 16). The chamber tomb is painted with subjects connected to the cavalry world and to the cure of male body. The tomb can be dated to the middle of the $4^{\text {th }}$ century B.C. (Mannino, 2003: 715, pl. XXIII, 2-3), more precisely to the third quarter, on the basis of the analysis of grave goods (Faklaris, 1985). As Polito reports, the Makryghialos tomb shows painted representations of a sword and of horse «finimenti» (Polito, 1998: 75). Another tomb with a similar decoration, still unpublished, is in Pydna (Polito, 1998: 94) and, always according to Polito, another one discovered in the zone of Tanagra shall also be considered. In the latter a horse protome and a sword, that is no longer visible, are painted on the walls

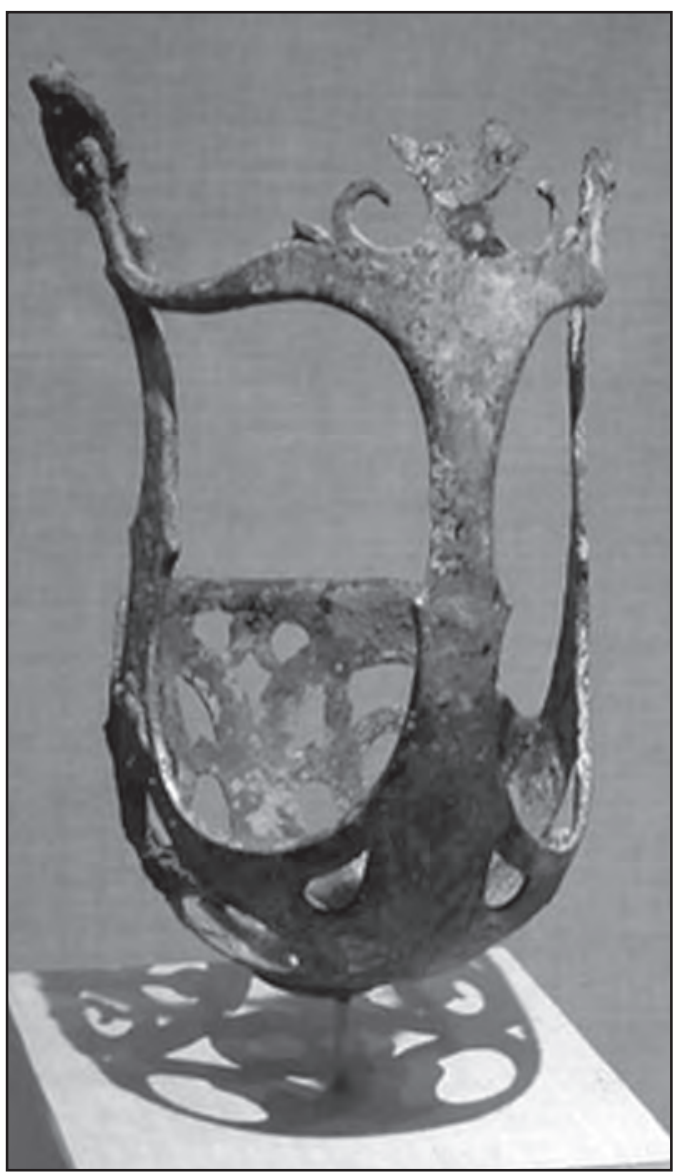


(Polito, 1998: 75). A similar representation, always connected to horsemanship, can be found inside a tomb in Southern Italy, where a prometopidion appears to be painted (Daremberg, Saglio, 1887: 251, fig. 299).

\subsection{TYPE 2 (fig. 17)}

The type 2 is defined by the absence of a bowl guard on the lower part, but shares some structural elements with the sub-

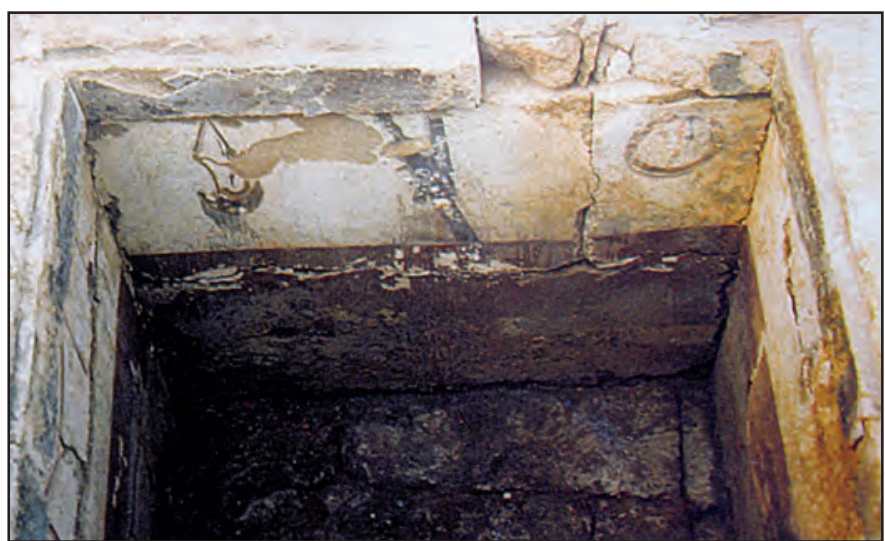

Figure 16. Painted muzzle of 1.A type from a grave of Makryghialos (Pidna, Macedonia), 350-325 a.C., (Polito, 1998: 75). type $1 . B$, namely the frontal bar with a decoration on the central part. As in the case of subtype 1.B, the decorations can present floral and geometric patterns; carved lines are traced on the surface of arms and tensors, thus defining the eyes, and sometimes can be found on the lower part of the frontlet, completing their decoration. The arms are

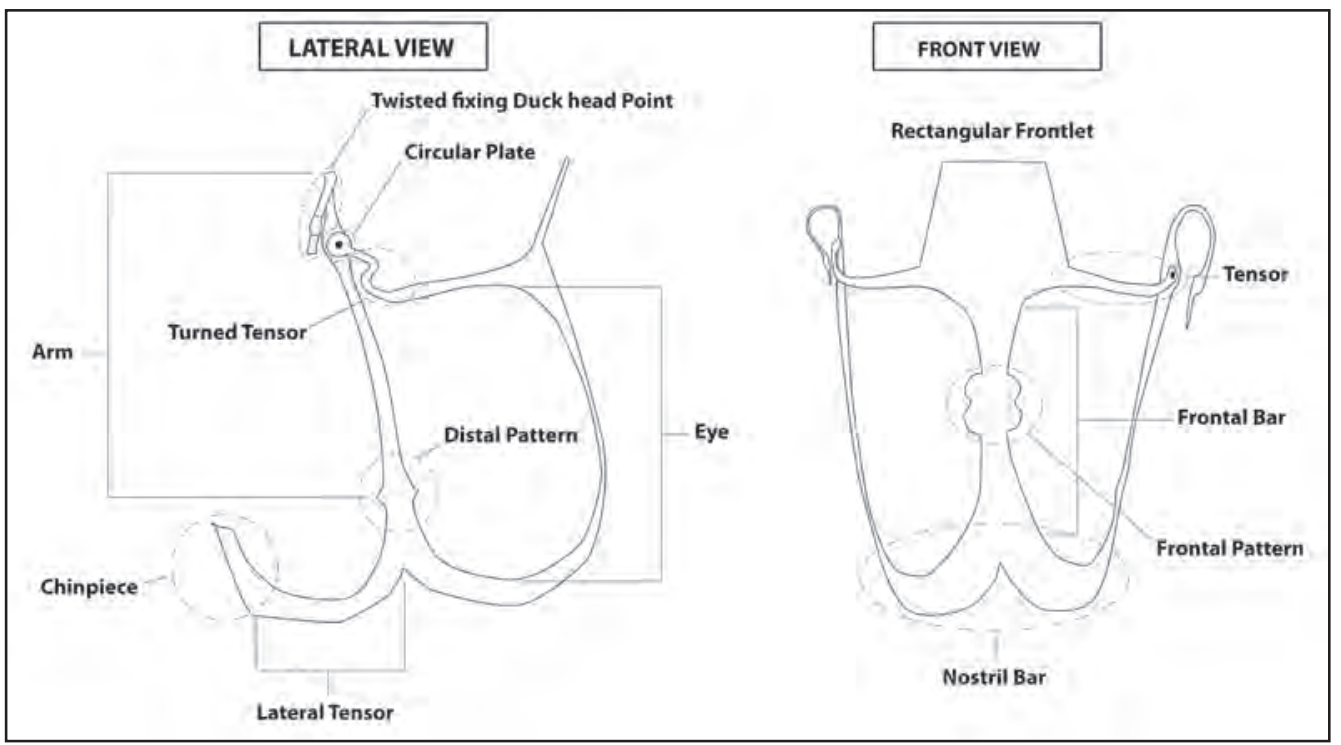

Figure 17. Structural scheme of 2 type muzzles.

embellished with floral, geometric and rhombus-shaped patterns and, as in the subtype 1.B, the tips of the arms can be shaped in form of a duck-head, rolled up to host a small ring. Duckheads are more frequently found in the $5^{\text {th }}$ century B.C. and became more common during the $3^{\text {rd }}$ century, when one can notice a development of their rendering, these being reduced to a flat and wide beak, which implies a progressive deconstruction of the figure, corresponding to an abandon of Classical and Hellenistic realism in favour of a mere decorative value of the pattern. 


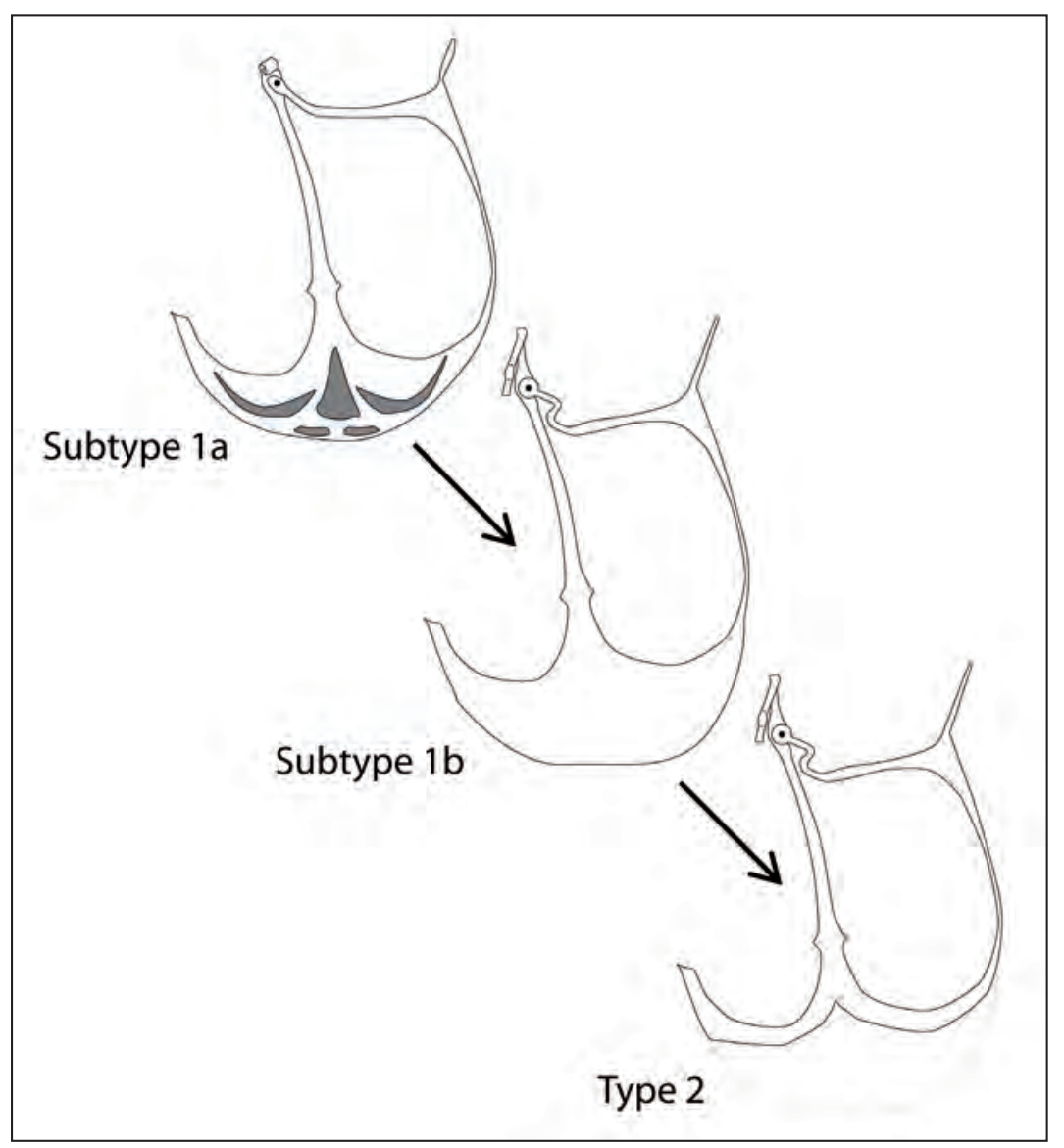

Figure 18. Typological evolution.

The frontlet consists of a lamina with incision, openwork patterns or figurative elements; its most common shape is the rectangular one. The tensors turn abruptly at their extremities and form an «S», this one being ended by a disc that is fixed to the arm through a rivet (fig. 18).

The type 2 is represented in the Iberian Peninsula by three exemplars at least: the one discovered about one century ago by Siret in Villaricos (Almería), kept in the Archeological Museum of Madrid (N. Inv. 2006/52/1189bis) (Siret, 1906: pl. VI, 34; Schüle, 1969: pl. 181, 3); a second one from Botorrita (Zaragoza), now in the Museum of Zaragoza, of which only a picture has been published (AA.VV., 1990: 315); a third one from Sangüesa (Navarra) (García y Bellido, 1931; García-Bellido, 1993: pl. 44 and front page).

The Peninsular exemplars lack of a reliable context; the muzzle from Villaricos, even though found during an old excavation, comes from a cistern placed next to an house settled on the top of the acropolis (Siret, 1906: 9-12) and appeared in a Roman republican context (although for some objects a slightly earlier chronology has been proposed, around the end of the $3^{\text {rd }}$ century B.C., mostly depending on the Montefortino helmet found in the house next to the cistern) (Garcia-Mauriño, 1993: 120-121). The muzzle from Botorrita should be dated earlier than the second quarter of the $1^{\text {st }}$ century B.C., when the site was destroyed during the Sertorian war (ca. 77 B.C.). Schüle once compared the muzzle in the Museum of Madrid and the one from La Pedrera, even though he had dated both of them to two different chronologi- 


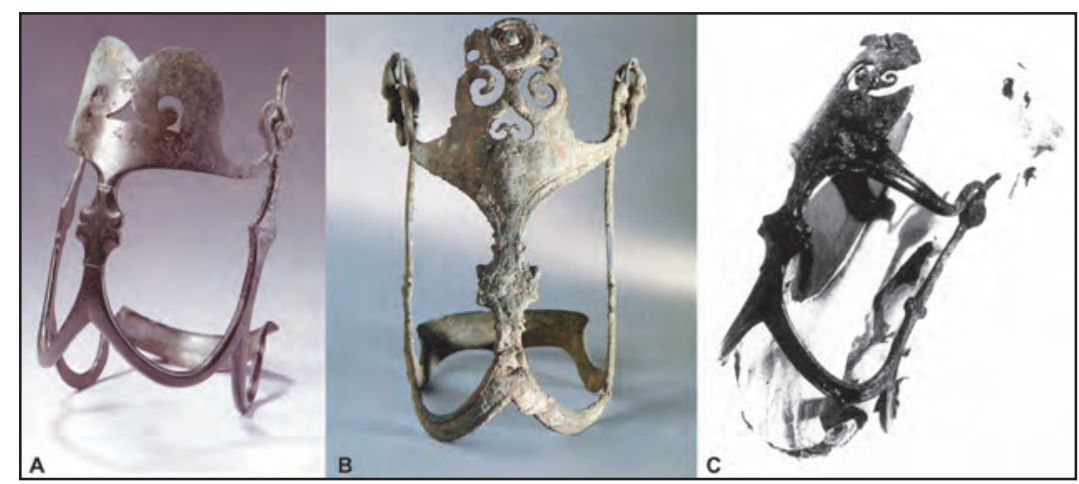

Figure 19. Muzzles from the 2 type: A. La Boisselière Coll. (Bozet, 2007b: 185); B. Pompei (Borriello, 1999: 151); C. Este (LaGenière 1997: 264).

cal moments - the error got possibly worse after A. K. Taylor confounded the proveniences and attributed the Madrid muzzle to Lleida (Taylor, 1975: 130)-. Nowadays the change of the chronologies allows a comparison of these two objects.

The archaeological context is a problem even for non-Peninsular muzzles, like the one from Pompeii, dated before 79 A.D. (Pernice, 1896: 12; Borriello, 1999: 151) (fig. 19). A better documented case is the one of a muzzle in the necropolis of Este (I.G. 3230), found in situ on a horse's skull and dated to the $4^{\text {th }}$ century B.C. It has served as a parallel for the muzzle from the Vigna Nuova sanctuary in Crotone (LaGenière, 1997: 264).

\subsection{TYPE 3}

Even though the aim of this work is to consider typology that can be found in the Iberian Peninsula, it seems convenient to include a third type of muzzles that is not attested in the Peninsula, because of their chronological affinity with the muzzles already discussed (fig. 20).

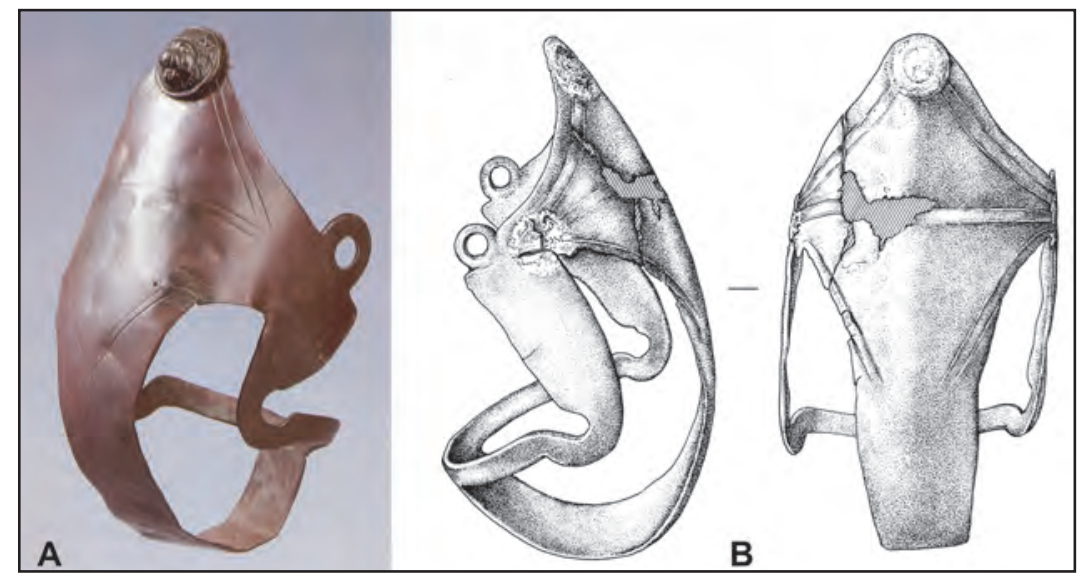

Figure 20. Type 3 muzzles: a) Western Anatolia, (Lawson, 1978: fig. 7); b) La Boisselière Coll. (Bozet, 2007a: 184). 
We know only two exemplars, the first generically indicated as coming from western Anatolia (Lawson, 1978: 140-143, fig. 7; Schwinden, 1987: fig. 3), the second part of the De La Boisselière collection of Brussels (N. Inv. D-218), whose provenience is unknown, even though a Gallo-Roman attribution, that we consider groundless, has been proposed (Bozet, 2007a: 184). In both cases, the snout of the horse is shut perpendicularly by means of a muzzle's prolongation with the form of a curved strip, thus forming the frontlet and the chinpiece at the same time. It is strengthened through two curved strips that give way to both sides of the snout and have a twisted fixing point to fit the bit. A triangular extension supports the decorative element, whereas the joining to the rest of the headstall is realized through two fixed rings. Both exemplars share the decoration on the bridge, composed by a double rhomboidal incision, divided in the middle into two triangles. The decoration is concluded by the addition, on the upper part, of a circular application, containing an embossed lion's head, preserved on the muzzle from the collection La Boisselière, but lost, although probably very similar, on the Anatolian exemplar.

We do not have a trustable dating for these muzzle-halters. Triangular muzzles painted on a pelike of the Policoro Painter, already mentioned above at the beginning of this work, could be a clue to suppose an ancient origin of the type, starting from the $4^{\text {th }}$ century B.C., maybe from a Greek milieu; even Lawson has proposed an origin anterior to the one of the Roman frontlets, being those common between the $1^{\text {st }}$ century B.C. and the $1^{\text {st }}$ century A.D.

\section{CATALOGUE OF THE PENINSULAR EXEMPLARS}

\subsection{TYPE 1}

\subsubsection{Necropolis of La Pedrera (Térmens ${ }^{6}$, Lleida). Muzzle n. 1 (fig. 21)}

Archaeological context: the main part of the associated objects and the context are unknown, despite a publication by E. Ripoll (1959: 276) in which a tomb of the necropolis was described: «in addition to the cinerary urn, a horse had been buried, as well as other associated grave goods: one typical falcata with traces of damascening, well preserved; an iron helmet; some bronze fibulas, bracelets and other ornaments; a bronze patera; a small figure of a hind; a tahali with inlaid with silver; a stylized human head of limestone...». The note has been traditionally interpreted as referring to the remains of a complex tomb with a buried horse (Plens, 1986: figs. 75-76; Plens, Rafel, 2002: 256, fig. 25) (fig. 6). This burial was dated between the end of the $7^{\text {th }}$ century and the beginning of the $6^{\text {th }}$ century B.C. (Maya, 1986: 43; Garcés et al., 1997: 14; Gómez, 2003: 211; Junyent, 2003: 96), but the chronology has been refused on the basis of the typology of horse bits and other grave goods (Graells, 2007; 2009; in press, 2011).

The muzzle from La Pedrera, did not seem to be associated to horse's bones, according to the existing photographs and in spite of Ripoll's and Maluquer de Motes' assertions (Ripoll, 1959: 276; Maluquer de Motes, 1968: 73). The wrong indication could maybe depend on a misinterpretation of an iron bit that seems to have been fallen from the lower part of a horse's skull, republished in several occasions (Maya, 1986: 43; Plens, Rafel, 2002; Garcés, 2007). On

6 The village discovered by J. Maluquer de Motes is located on the border of the municipal district of Vallfogona de Balaguer, but the necropolis lies beyond the modern delimitation and is included for a wide portion into the district of Térmens. 


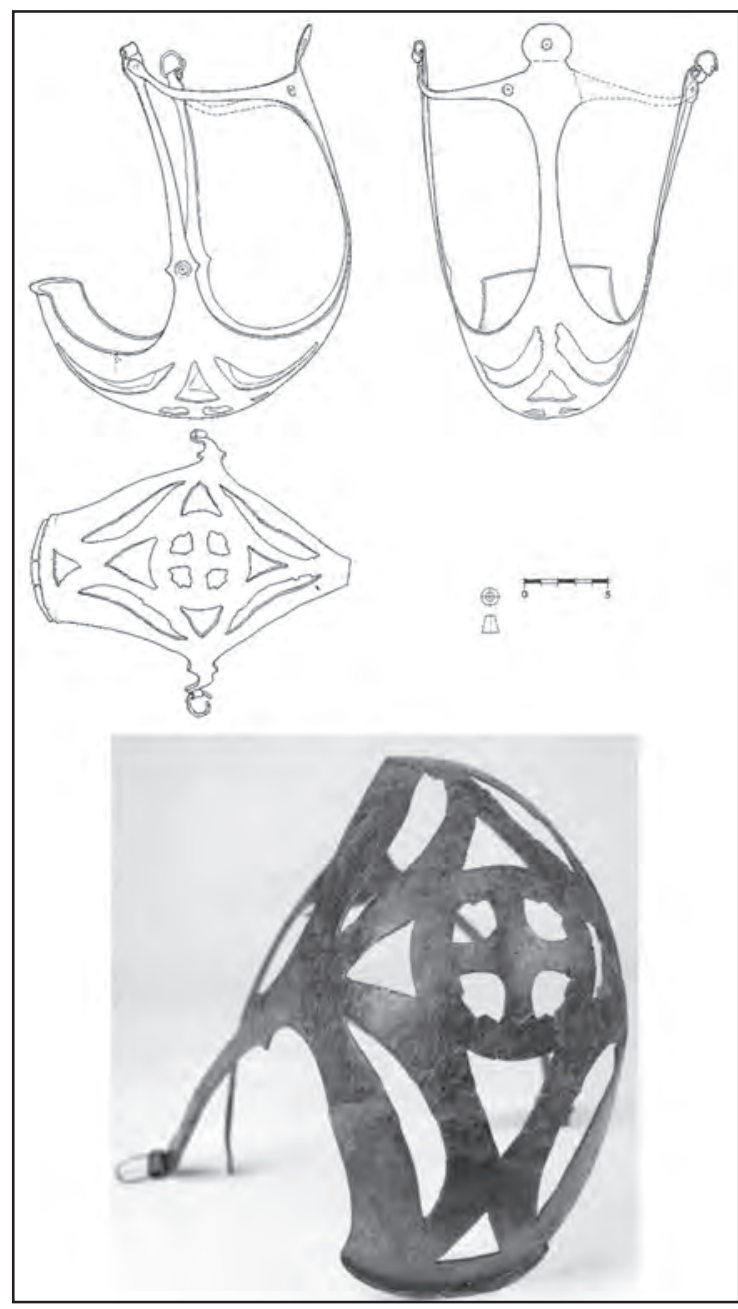

Figure 21. Muzzle n. 1 from La Pedrera (Térmes, Lleida), Museu de Lleida, (Photo: Museu de Lleida Diocesà i comarcal (J. V. Pou); Drawing: J.L. Ribes, Garcés, 2002b: 198-199). this matter, among the scarce information available there is a short photo caption written by R. Pita (1975: 149), where it is said that the muzzle was found inside an incineration tomb with an urn, placed «between» the skeletons of two horses. This possibility matches better with the pictures; the muzzle may have come to light «between» the horses, not above any of them. In the available pictures it appears in situ and turned face up, which is difficult to believe, even supposing that the corresponding bones have been previously removed. For local scholars this fact was sufficient enough to suppose the presence of a «tomb with chariot» of Central European type, and, due to the lack of more convincing evidences, they supposed the chariot to be completely made of wood, without any metallic part employed for the construction (Pita, 1975: 149). It is no use to repeat that modern investigations have shown an evident and correct scepticism in relation to the existence of this wagon, considered the lack of any other evidence (Plens, 1986; Plens, Rafel, 2002: 256).

Finally, the bronze muzzle did not surround any horse's skull, though being related to the remains of a jointed iron bit, held by an anonymous hand on one picture. The muzzle could have possibly been removed from one of the animals before a sacrifice, but even other hypothesis could be suggested, for example the one of a deposition as symbolic memory. Among many European cultures, especially in the Gallic one, it is not infrequent to indicate horses in an indirect way, maybe even symbolic, by means of tack elements, especially bites, placed among grave goods. It has to be said that a sacrifice of the horse is very uncommon, both among Iberians (but exceptions are known) and, in contrast with the common opinion, Gauls, since horse's bones remains inside Gallic graves are very rare, as scholars have noticed. So, inside authentic tombs with chariots, typical at the beginning of the second Iron Age, especially in the region of Champagne, horses have not been buried together with the deceased (Gabaldón, 2005: 268). Complete horses in French necropolis should be interpreted as isolated cases.

Current location: Museu Diocesà i Comarcal de Lleida, N. Inv. L-1211.

Description: as the majority of the exemplars of this typology, it was realized in one single piece $^{7}$. It shows just damage on the left tensor, broken on the central part of the muzzle's front

7 The only exception is the exemplar from Vigna Nuova in Crotone (LaGenière, 1997). 
and absent by the connection with the arm. Otherwise it keeps the left ring that served to the connection of the harness secured to both twisted fixing points.

The central pattern has a circular shape, as on the exemplars of the Archaeological Museum of Barcelona and of the White and Levy collection, as well as on the Boeotian muzzle. Despite this fact, there are some light differences between these muzzles, because on the one from La Pedrera and on the exemplar in Barcelona the central pattern is plain. The muzzle from Boeotia (Pernice, 1896, pl. 1), on the contrary, shows a floral appliqué on the frontal pattern, whereas the muzzle in the White and Levy collection has two small knobs on the sides (the latter maybe anticipating a rectangular or trapezoidal frontlet).

Decoration: as central pattern, the bowl guard shows a openwork circle parted into four portions, each surrounded by four holes of triangular shape with a radial disposition that follows the axis of the circle; four holes, half-moon shaped, connect the triangles' vertices, and a last one, triangular, is realized on the lower part of the muzzle's chinpiece.

The decoration is completed by small circles pressed, respectively, in the middle of the distal rhombus, by the eye's angle next to the joint between the tensors and the frontal bar, and, finally, in the middle of the frontal pattern.

Dimensions: length: $21.6 \mathrm{~cm}$; max. width: $10 \mathrm{~cm}$; diameter of the bowl guard: $8.7 \mathrm{~cm}$.

Bibliography: Schüle, 1969; Lara, 1974: 91, fig. 64; Pita, 1975: 149; Maya, 1986; Plens, 1986: figs. 75-76; Garcés et al., 1997: 14; Garcés, 2002a: 198-199; Plens, Rafel, 2002: 256, fig. 25; Gómez, 2003: 211; Junyent, 2003: 96; Graells, 2007; 2009; in press, 2011.

\subsubsection{Necropolis of La Pedrera (Térmens, Lleida). Muzzle n. 2 (fig. 22)}

Archaeological context: associated objects and context unknown.

Current location: Museu Diocesà i Comarcal de Lleida, N. Inv. L-10077.

Description: fragmented and folded on itself. Only the right side is preserved. Several evidences of ancient reparations are shown by six holes for rivets.

The twisted fixing point is located on the top of the arm, in order to connect the tensor and guarantee rigidity. On the other side, the bowl guard shows six holes: five are hollow; the sixth still presents its rivet. The six holes have different diameters and are disposed irregularly. It is undoubtedly an ancient reparation that demonstrates the value of the muzzle.

The distal rhombus has got only one vertex, namely the one projected inside the muzzle's eye, as in the exemplar published by Pernice (1896; Anderson, 1961: 56, n. 9). The bowl guard does not show any trace of openwork decoration, normally visible on the surface preserved.

Decoration: on this exemplar it is concentrated on the side of the arm and on the central part of the bowl guard's side. Deep carved lines ornate the arm. The central part of the bowl guard is more complex, embellished with a mixture of thin carved lines that follow the openwork pattern, forming in its central part a vertex where three little circles have been engraved using a matrix. The three circles are disposed to form a triangle, being the central one bigger than the other two.

Dimensions: max. length: $20.5 \mathrm{~cm}$; width (by the arm): $1.5 \mathrm{~cm}$.

Bibliography: Graells, 2009, in press, 2011.

\subsubsection{Provenance unknown. Museu d'Arqueologia de Catalunya-Barcelona (fig. 23)}

Archaeological context: context and provenance unknown. In the winter 2005 one of us (I.G.) casually noticed a bronze muzzle on view in the display case n. 1, room 21 of the Ar- 


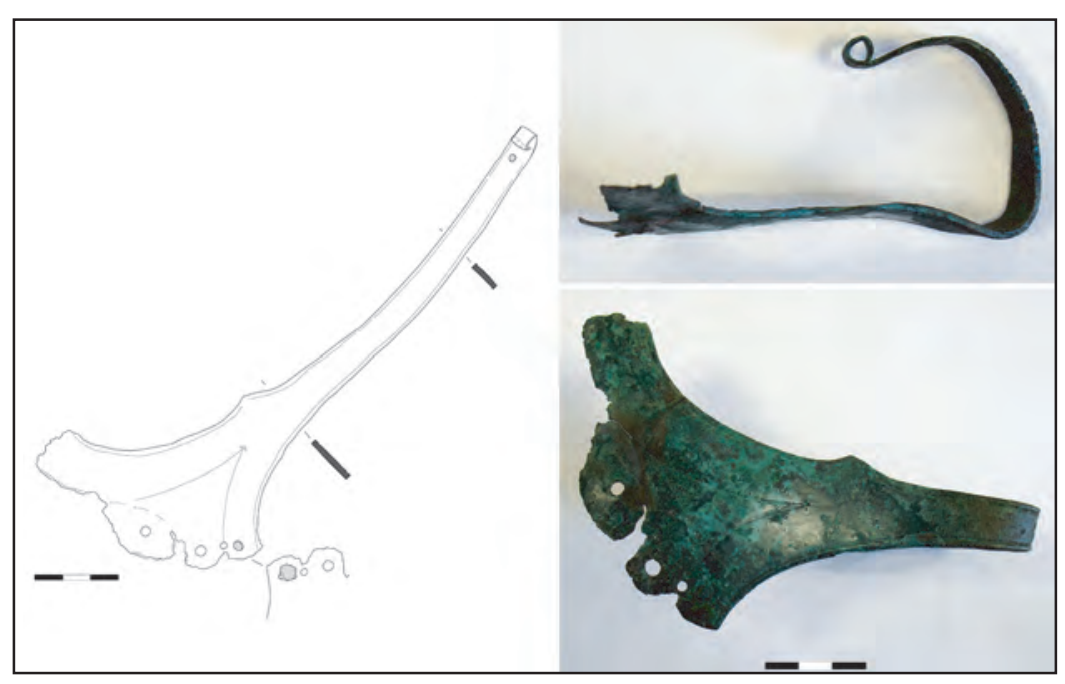

Figure 22. Muzzle n. 2 from La Pedrera (Térmes, Lleida), Museu de Lleida Diocesà i comarcal, (Photo and Drawing: R. Graells, Graells 2009: figs. 236-237).

chaeological Museum of Barcelona - the section dedicated to Hellenistic and Roman bronzes ${ }^{8}$ - acquired under the direction of Martín Almagro Basch. In the inventory book the muzzle is the first one of a short list of nine objects, all made of bronze and of unknown provenance, apparently without any relation between each other. The Museum's staff told us that the muzzle as been exposed for many years in the same point, probably since the opening of the Roman rooms, which take us back to 1954 (AA.VV., 1958: 134), even though this section of the Museum has been modified afterwards. The guide of those years (Almagro, 1955: 111) does not allow us to confirm this fact, being the catalogue not exhaustive ${ }^{9}$; the following reeditions of the same catalogue do not solve the doubts, since bronze harness for horses are just superficially mentioned (Ripoll et al., 1981: 140). It is almost a paradox that this object was known before, even considering the muzzle from La Pedrera, discovered in 1958, which shows many analogies to this one, and that nobody has compared the two exemplars so far. In this respect nothing allows us to affirm that the object comes from the Peninsula.

Current location: Museu d'Arqueologia de Catalunya-Barcelona, N. Inv. 15.806.

Description: muzzle consisting of one piece, with a bowl guard finished off in the chinpiece with a small external projection; three rigid strips, as usual, two arms and the central bar. The distal rhombus does not show the negative of small appliqués, as one can see in this same sector on the muzzle from La Pedrera, maybe because of its worse preservation status or, perhaps, due to the alternative suggested by two small holes on the lower top of the above mentioned strips, with a hook-shaped extremity in order to fix individual rings, unfortunately not preserved. The frontlet is very thin and in the present condition of the muzzle seems slightly twisted, being the whole object a little bit distorted. The bridge was connected to the arms by means of two little rivets (only the right one is preserved); the tensors' body twists

8 We'd like to thank Mr. Xavier Aquilué, former director of the Museum, for helping us to study this halter. We'd even like to express our gratitude towards the curators, Mrs. Teresa Carreras and Mrs. Teresa Llecha, who helped us with the work, and to Mr. Ramón Álvarez Arza, technician of the UB, for the drawings and the photographs of the object.

9 «Here is collected an interesting group of Roman and of some Hellenistic bronzes, mostly coming from Antiquity dealers and some of them from Mérida and the surrounding area» (Almagro, 1955: 110). 


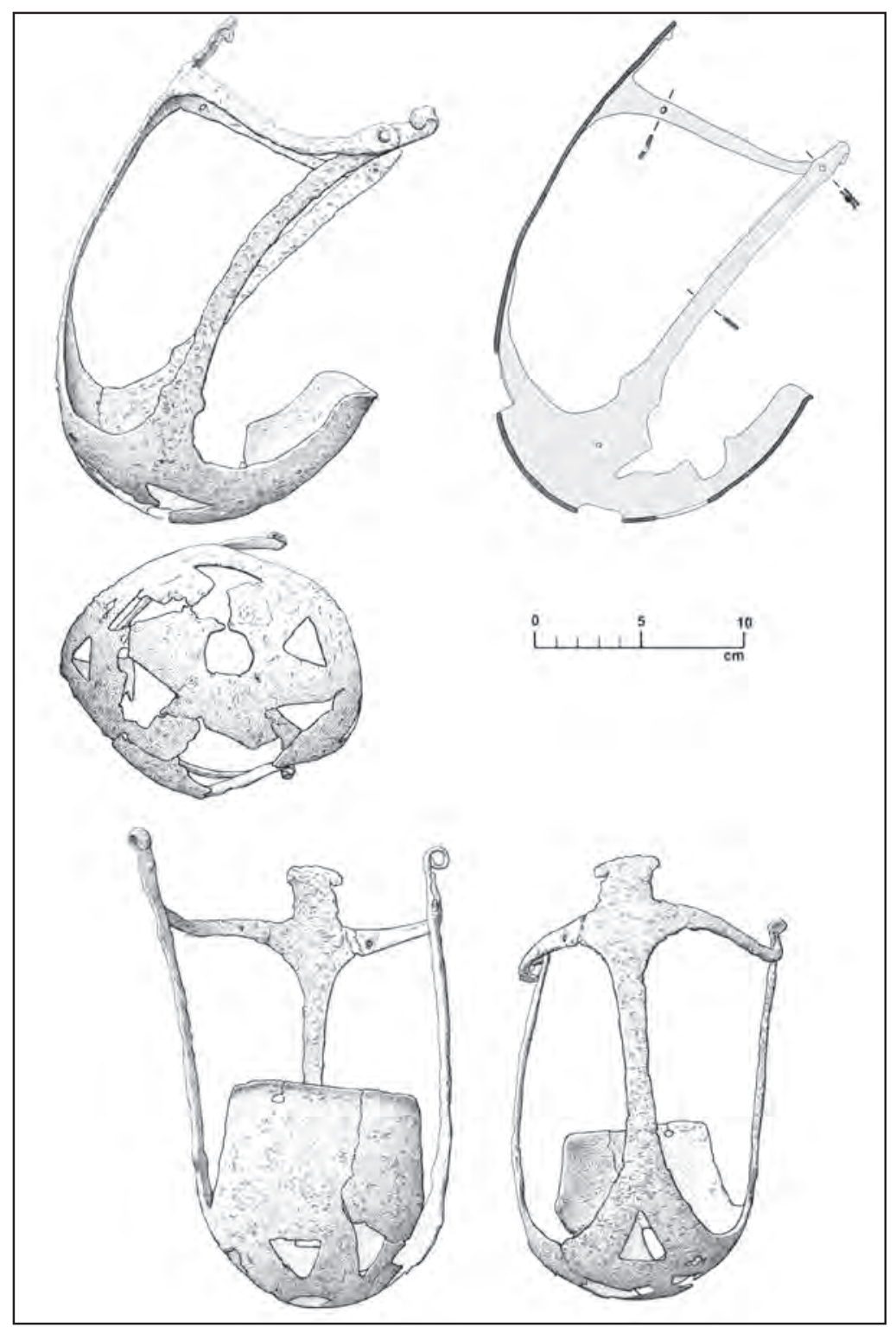

Figure 23. Muzzle from Museu d'Arqueologia de Catalunya-Barcelona, (Drawing: R. Álvarez).

and the right one has a small hole next to the twisted fixing point. The joint between the frontal bar and the tensors is surmounted by the frontlet, a projection that today is much damaged, but originally of circular shape.

Decoration: the bowl guard has been treated with an openwork decoration and the resulting pattern is a small central circle (diameter: $2 \mathrm{~cm}$ ), surrounded by six triangles whose sides range between 2.5 and $3 \mathrm{~cm}$. Even though the present damages make the interpretation more difficult, the sequence of the decoration can be easily reconstructed. A seventh openwork triangle appears nearby the union of the bowl guard with the frontal bar, that in this point seems to split in two parts. 
Dimensions: max. length: $23 \mathrm{~cm}$; max. width: $16 \mathrm{~cm}$; diameter of the bowl guard: $10 \mathrm{~cm}$; length of the bowl guard: $12.5 \mathrm{~cm}$. The measures are lightly bigger than the ones of the muzzle from La Pedrera, even if the proportions are the same.

Bibliography: unpublished, mentioned in Quesada, 2005: 125.

\subsubsection{Provenance unknown. Archaeology Section of Valencia (Fig. 24)}

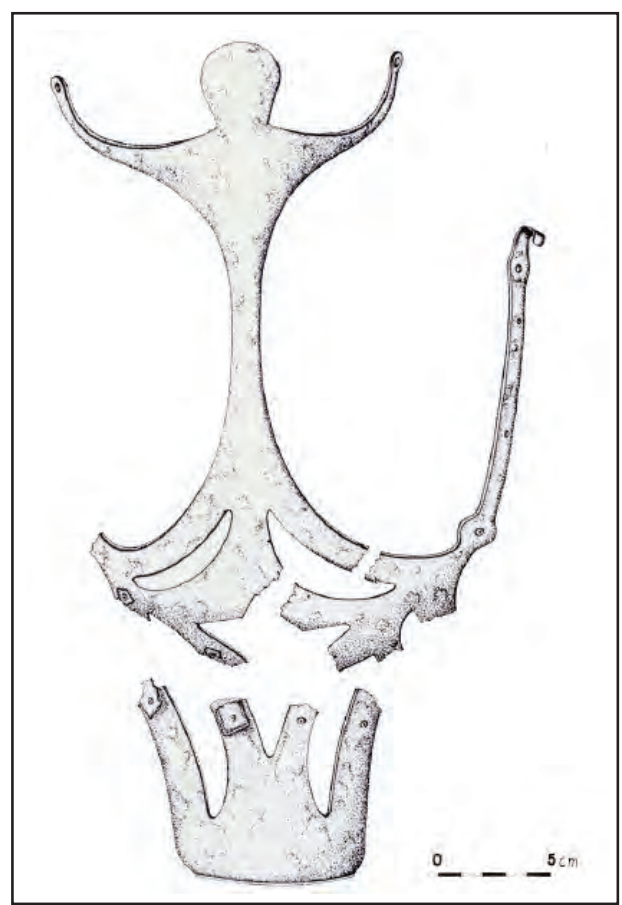

Figure 24. Muzzle from Archaeology Section of Valencia (Soriano, 1991: fig. 43).

Archaeological context: context unknown, now kept in the Archaeology Section of Valencia without other information about its provenience ${ }^{10}$.

Current location: Archaeological Museum of Valencia, N. Inv. 333.

Description: as the majority of the exemplars of this typology, it was realized in one single piece ${ }^{11}$. But this issue is broken into three fragments: the first integrates the Frontlet, the Tensors, the Frontal Bar and the right upper quarter of the Bowl Guard. The second is the back of the Bowl Guard and the closure of the Chinpiece. The third is the left Arm and the left upper quarter of the Bowl Guard.

It shows an ancient break and a restoration on the frontal part of the Bowl guard, as demonstrate four couples of holes between the openwork holes of the Central pattern, four holes still have fragments of metal sheet riveted. The central pattern is indeterminate, but the Distal Rhombus is a disk with a small central perforation. Finally, the Arm has an unusual hole in the middle.

Decoration: as central pattern, the bowl guard shows an openwork combination of arcs, minimum four, half-moon shaped, connect the triangles' vertices.

The decoration is completed by one small circle pressed in the middle of the distal rhombus. Dimensions: length: $33.3 \mathrm{~cm}$; max. width: - cm; diameter of the bowl guard: - $\mathrm{cm}$.

Bibliography: Soriano, 1991: 29, Fig. 43.

\subsection{TYPE 2}

\subsubsection{Villaricos (Almería) (figs. 25, 26)}

Archaeological context: from a cistern situated next to a house that once stood on the top of the acropolis (Siret, 1906: 9-12) ${ }^{12}$. Roman republican objects were found inside the cistern,

\footnotetext{
10 We would like to thank Dra. M. Barril and Mr. E. Galán the reference to this issue.

11 Vigna Nuova in Crotone (LaGenière, 1997).

12 We'd like to thank Mrs. Margarita Moreno Conde, technician of the Classical Antiquity department in the National Archaeological Museum of Madrid, for having helped us with the study of this and of other halters that we will mention later.
} 


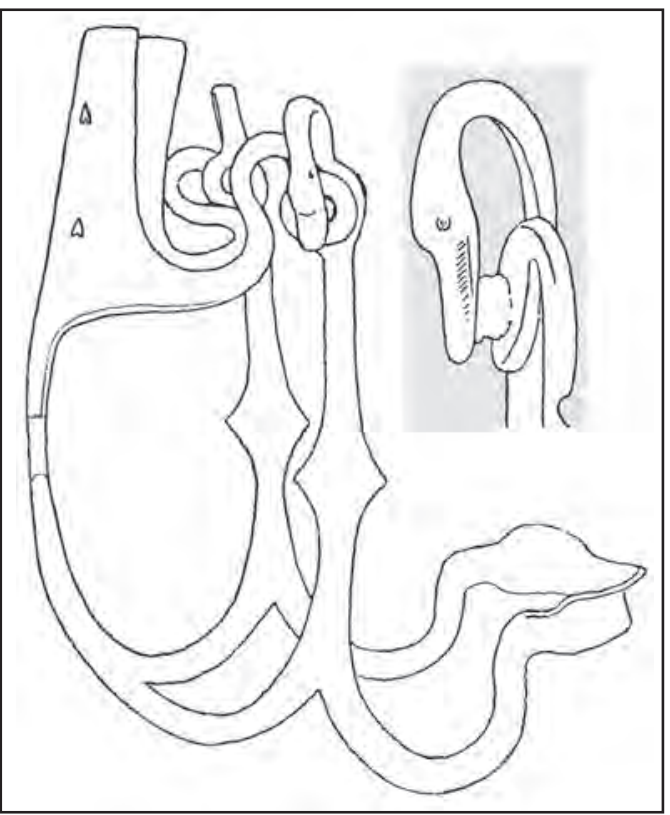

Figure 25. Muzzle from Villaricos (Almería) (Drawing: R. Álvarez based on a L. Siret's drawing -1906: lám. VI, 34 y 34’-). namely poorly accurate artefacts as common pottery and several metallic elements, among which there was an arched fibula, a sword handle and a bronze simpulum with duckhead. There was a house directly connected to the cistern, where a Campanian pyxis of the same chronology as the pottery in the cistern and some metallic items have been found. For these objects an earlier chronology has been proposed, around the end of the $3^{\text {rd }}$ century B.C., especially considering the presence of a helmet of the type «Montefortino» (GarcíaMauriño, 1993: 120-121).

Current location: National Archaeological Museum of Madrid, N. Inv. 2006/ 52/1189bis.

Description: probably made out of a single part. The chinpiece shows an alteration due to the bad conservation; the arms show distal rhombus. In L. Siret's publication (and in an unpublished drawing made by him, kept in the Museum of Madrid) the muzzle still had a duck-head shaped header with a long and flat beak on its left side. The object was badly restored later, the duck-head has been wrongly attached on the right side and a lateral arm has not been repaired. W. Schüle's publication shows the duck-head appliqué placed on the wrong side, including some staples added by the restorer in order to keep the broken fragments of the frontlet together, to be removed from the reproduction. The nostril bar shows a hexagonal enlargement, while the tensors have the usual «S» shaped termination. The frontlet is wide and rectangular.

Decoration: five small holes symmetrically disposed on the frontlet, one in the middle and the other four on the edges, maybe what remains of applied decoration. Four holes are lightly heartshaped, but the one up on the right is smaller and more circular. A little hole can be observed even on the lower part, in central position.

Dimensions: length: $20.8 \mathrm{~cm}$; width: $14 \mathrm{~cm}$; height: $15.4 \mathrm{~cm}$.

Bibliography: Siret, 1906: pl. VI, 34 and 34'; Schüle, 1969: pl. 181, 3.

Figure 26. Muzzle from Villaricos (Almería) (Photo: R. Álvarez).

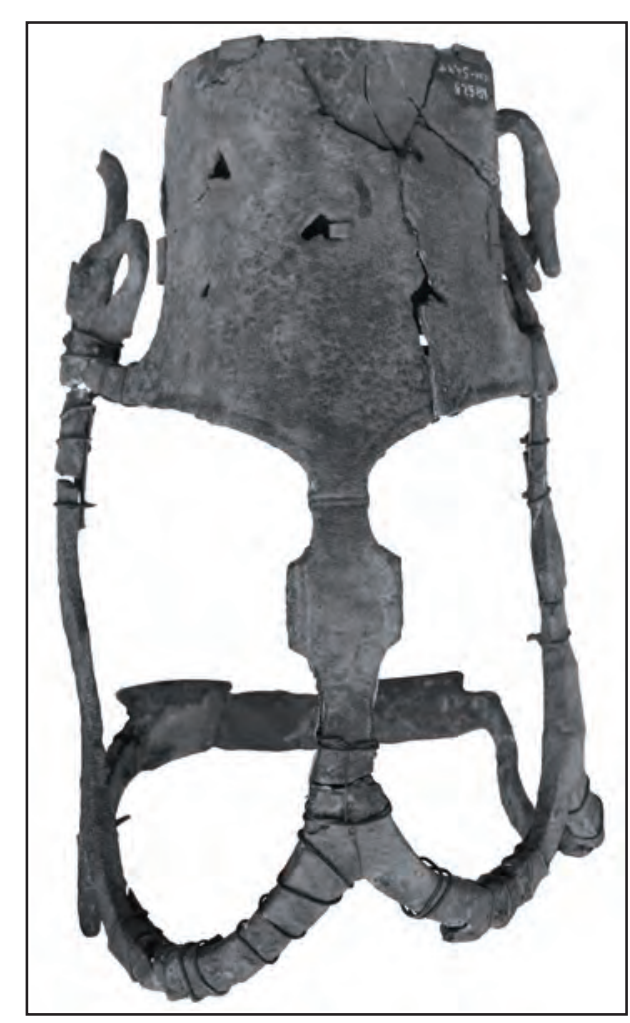




\subsubsection{Contrebia Belaisca (Botorrita, Zaragoza) (fig. 27)}

Archaeological context: the context of this object is unknown. The site of Botorrita has been published many times, but a detailed one is still missing; for a general overview see the work of M. Beltrán Lloris (2005: 137-144). Although there are some precedents, the Celtiberian city reached its peak during the $2^{\text {nd }}$ and the beginning of the $1^{\text {st }}$ century B.C., being then destroyed during the Sertorian war, ca. 77 B.C. (Liv., Frag. 91).

Current location: Museum of Zaragoza, N. Inv. 83-40.3 BOT-fac.

Description: muzzle made out of a single bronze part, now fragmented. The chinpiece is quite curved at one top, the arms include distal rhombus and duck-head terminations. The nostril bar has a double-twisted decorative enlargement in the middle and the tensors have «S» shaped terminations. The frontlet is wide and rectangular, similar to the one of the exemplar from Villaricos.

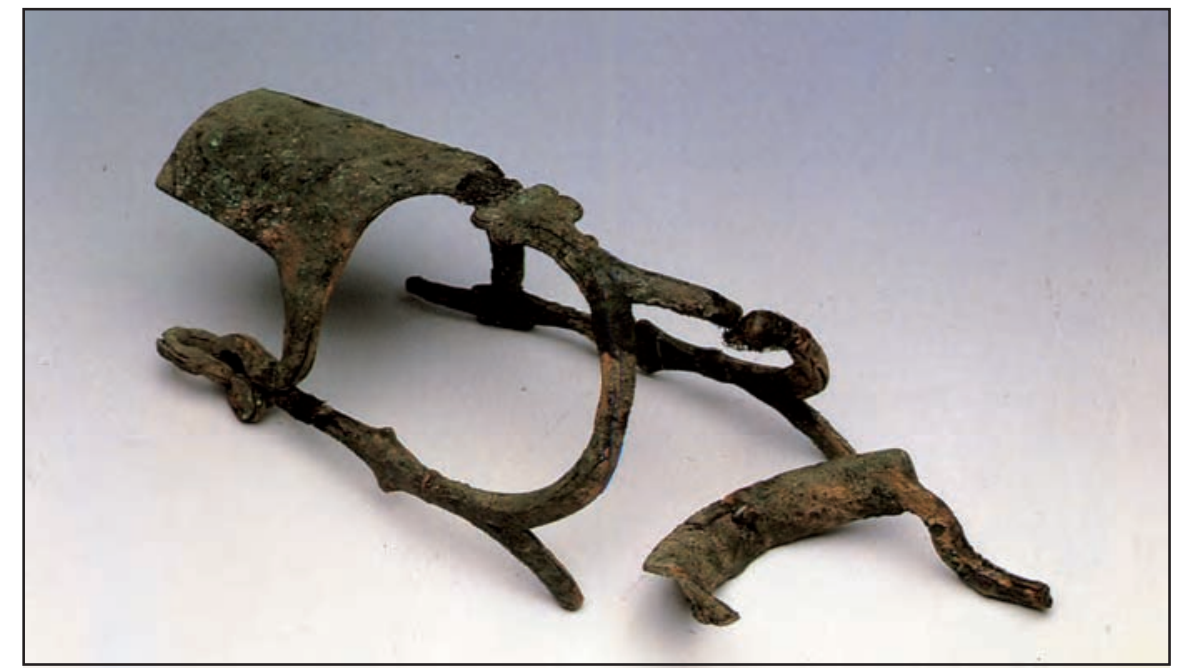

Figure 27. Muzzle from Botorrita (Zaragoza) (AA. VV., 1990: 315).

Decoration: no information available concerning the decoration of this object.

Dimensions: length: $22.5 \mathrm{~cm}$; height: $10.2 \mathrm{~cm}$; thickness: $0.5 \mathrm{~cm}$ (AA.VV., 1990: 315).

Bibliography: AA.VV., 1990: 315, n. cat. 290.

\subsubsection{Sangüesa (Navarra) (figs. 28, 29, 30)}

Archaeological context: context unknown, now kept in the National Archaeological Museum of Madrid and before in the collection of A. Vives, who acquired it from the Marqués de Casa Torres. The last one, in turn, purchased it on the art market. A. García y Bellido informs us about the acquisition date by the Museum of Madrid (19th august 1913) and collects a note of J. Cabré about a manuscript written by A. Vives, who indicates Sangüesa (Navarra) as provenance (García-Bellido, 1993: 234). The illustration connected to the manuscript was edited later (García-Bellido, 1993: 234).

Current location: National Archaeological Museum of Madrid, N. Inv. 22857. 
Description: the muzzle consists of a single bronze piece with characteristics of both the ancient and the modern phase (respectively, the eye and the open bowl guard). The arms do not include any distal rhombus, at whose place we encounter the joint between lateral tensors and nostril bar, the latter being divided on this exemplar into two segments rising from the frontal bar. The ending of the left twisted fixing point (the right one is not preserved) is duck-shaped. The frontlet consists of a rectangular plaque with complex decoration.

Decoration: the decoration is

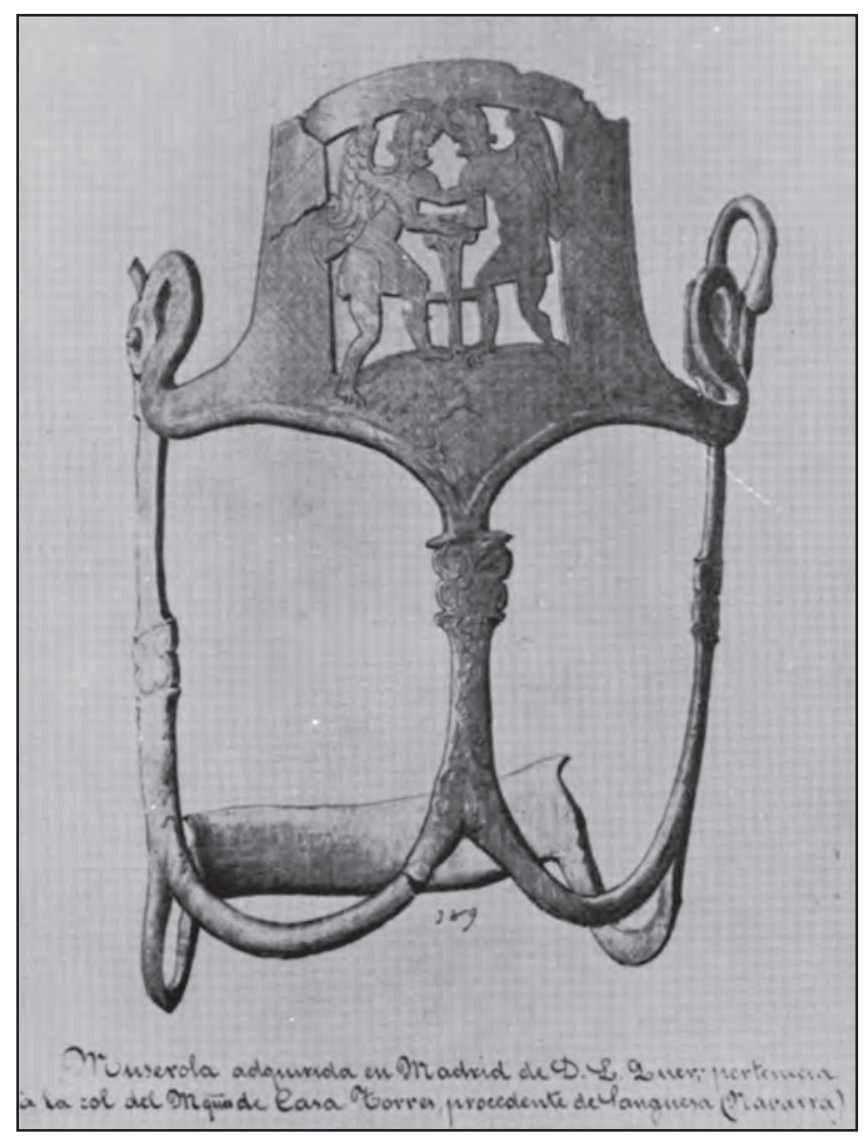

Figure 28. Muzzle from Sangüesa (Navarra) (Drawing: A. Vives, from García-Bellido, 1993: lám. 44). relevant in three different points of the muzzle: firstly, on the central part of the arms; secondly, at the beginning of the frontal bar; finally, on the central pattern. The decorative elements on the arms and on the central bar are floral, with a relevant abstract component, forming two opposed volutes framed by two flat bases. The frontlet has an openwork and incised rectangular pattern, that assembles a scene that includes two winged figures facing each other, placed around a vertical object in central position. The figures have a human body, but the wings suggest to interpret them as mythological beings. Their hairs are large and put up in buns, clearly visible on the back of the heads; short wings or feathers arise from the forehead. On the faces, though very schematic, it is possible to recognize noses and lips, the latter being particularly fleshy on the link figure. Two wings are visible on both figures: the wings of the link figure end with volutes, those of the right one are pointed; some

anchor-shaped incisions provide the plumage's details. The figures seem to grasp each other with their arms, forming a right angle. By the arms on foreground intertwined hands are visible, while the left figure fasten with the other arm the right one above his elbow. The bodies are represented lightly flexed and covered with a simple short tunic; the legs are uncovered and the feet are bare, as one can see from the detail of the toes, realized through incisions on the frontlet and running over the limit of the frame that encloses the scene. The central object, almost trapezoidal, comes up from the lower side of the scene and ends in correspondence of the arms on the foreground, forming a double volute. Two small rods depart from the centre of this object and connect the flexed knees of the two beings, giving thus stability to the structure.

In his interpretation of the scene, A. Vives considered the figures as angels around a cross, dating the object to the late Roman period (García-Bellido, 1993: 234), which is not possible. 


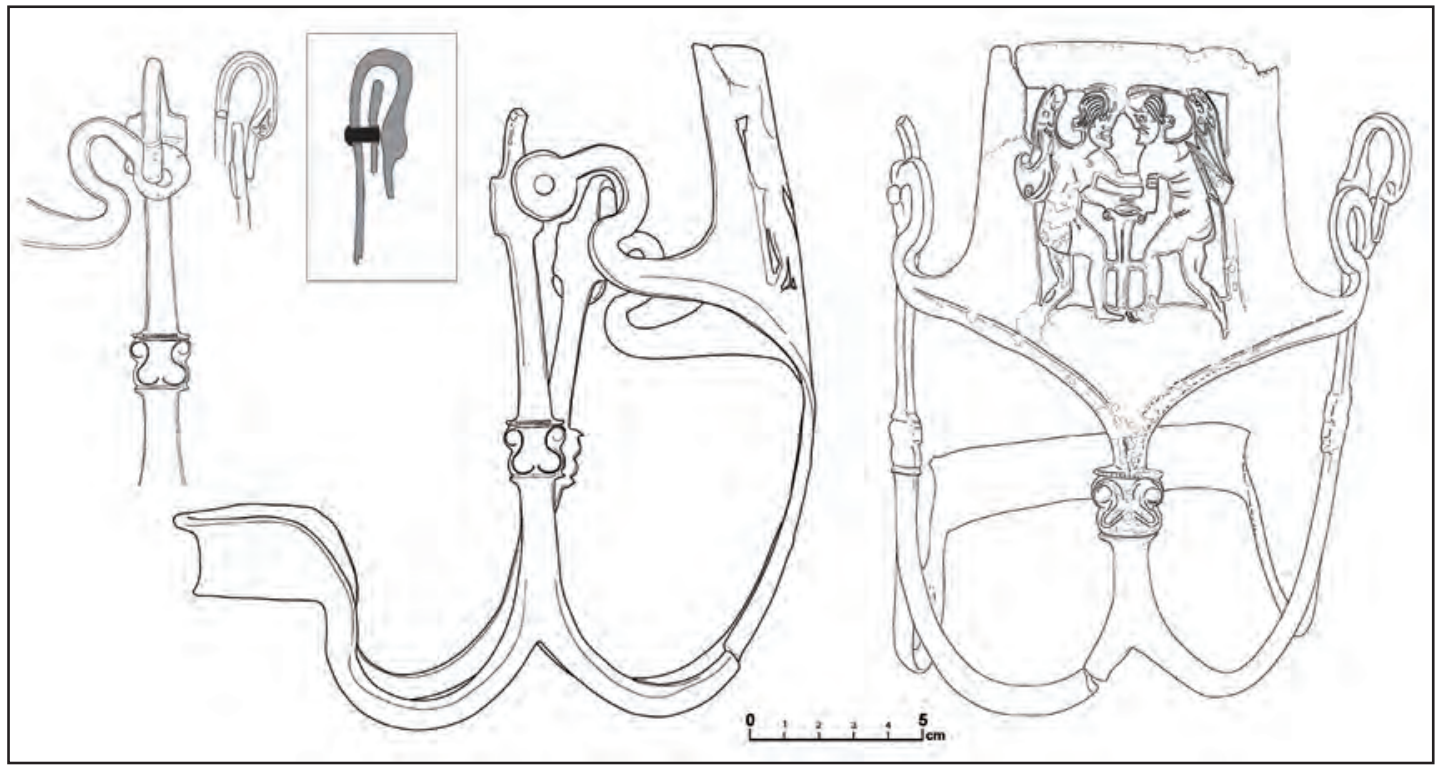

Figure 29. Muzzle from Sangüesa (Navarra) (Drawing: R. Álvarez).

A. García y Bellido, on the contrary, avoided to give a definitive interpretation ${ }^{13}$, but recalled the attention on those which he considered Etruscan winged genies, realized by means of an openwork technique. He compared the muzzle with the one from Pompeii, though setting for it an archaic chronology, when its presence in Navarra could have been justified on the basis of the commercial trades with Massalia and the Phocaeans (García y Bellido, 1931: 13-14).

The presence of some female traits on the figures allows us to advance the hypothesis of a scene related to the myth of the harpies fecundated by the wind Zephyr - maybe represented with the enigmatic object with volutes placed in the centre. According to the myth, in fact, the harpies gave birth to illustrious horses: the story seems to suit perfectly for a prestigious equestrian equipment. As mentioned in the Iliad (XVI, 149-151), the harpy Podarge, of equine aspect, was fecundated by Zephyr and gave birth to Achilles' horses, Xanthos and Balios ${ }^{14}$. Stesichorus hands down a more complex version of the myth, in which the same harpy gives birth to the above mentioned horses, taken by Poseidon and given to Here, who finally delivered them to the Dioscuri (Stesich., Fr. 1, 176-178). Finally, another version of this myth, more suitable to our scene, is the one in which the two horses are assigned to two different mothers: Xanthos to the harpy Aellopous and Balios to the harpy Podarge (Nonn., Dion. XXXVII, 155). This suggestion can be corroborated if we look to the descriptions of the most ancient Greek myths, where the harpies are normally two (Aello and Okypede) and have winged female bodies; even Hesiod describes as distinctive feature her beautiful hair (Teog., 265).

13 «The two figures seem to represent winged genies of violent appearance, almost like caricatures, fronting and grasping each other, as if they were fighting. They are completely naked and from their shoulders sprout wings, while smaller ones arise from the temples. Between them is placed an object of difficult interpretation, ending on its top with something resembling a very simple Ionian capital of barbarian aspect. It seems to divide the two figures, but in reality it is a technical device to connect the whole composition, as well as the little rods jointing the legs of the genies. Inside the silhouettes, thin carved lines mark the outline and depict anatomical details, hair and feathers». (García y Bellido, 1931: 12).

14 Some interesting reflections regarding Homer's tradition about the origin of the horse Xanthos can be read in Sarah Iles' work (Iles Johnston, 1992). 


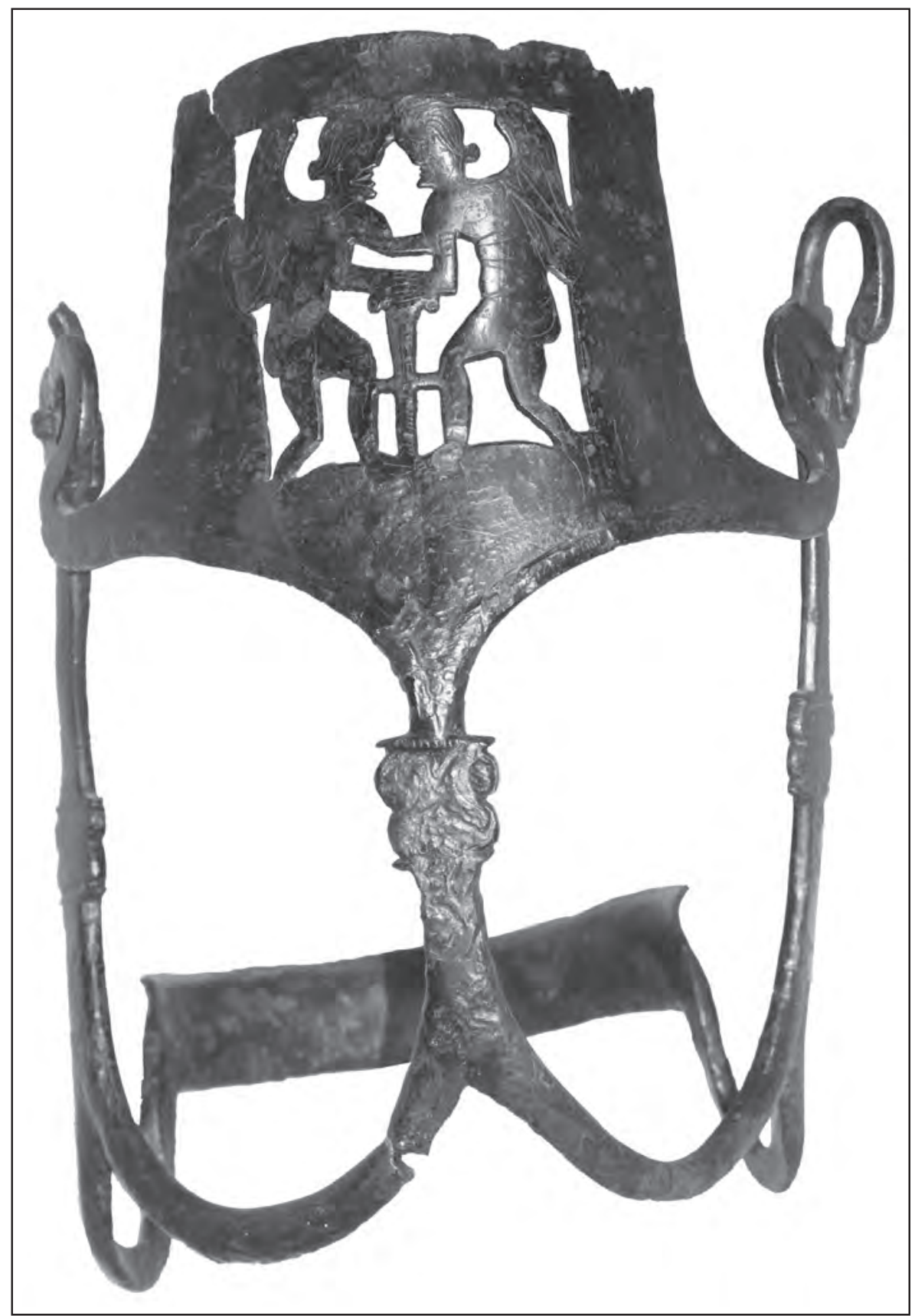

Figure 30. Muzzle from Sangüesa (Navarra) (Photo: R. Álvarez).

If A. García y Bellido, by interpreting the two figures as daimones, believed to see them fighting, their position do not really seem to be the more adequate for this purpose, since one would expect them to neutralize each other with the forearms, as the fighters in the Tomb of the Augurs in Tarquinia do (Pallottino, 1952: 37). The way the two winged figures hold each other using their hands and grabbing the arms seems to be more understandable if related to a mutual support - the scene curiously reminds one of two naked figures represented while 
crushing grapes and dancing rhythmically on the Grape Harvest mosaic (Mosaico della Vendemmia) found in Rome, on the Oppio ( $1^{\text {st }}$ century A.D.). We can suppose that the two harpies support each other to face the irruption of the divine and, therefore, formidable wind that surprises them.

Other mythological scenes are represented on the muzzle from Vigna Nuova in Crotone, where the little Heracles strangles the snakes (LaGenière, 1997), and on the muzzle of the British Museum, with the representation of a griffin. All these decorations are undoubtedly pre-Roman.

Dimensions: length: $19.3 \mathrm{~cm}$; width: $15 \mathrm{~cm}$; depth: $18 \mathrm{~cm}$ (García-Bellido, 1993: 234).

Bibliography: García y Bellido, 1931; García-Bellido, 1993: 234, n. 389.

\section{CONCLUSIONS}

It can reasonably be inferred that muzzles with bowl guard made out of perishable materials were used by horse grooms, as written by Xenophon in the $4^{\text {th }}$ century B.C., and that maybe they were known since the $6^{\text {th }}$ century B.C., according to their representations on Attic black figure vases. The first metallic muzzles can be dated to the first half of the $5^{\text {th }}$ century B.C., according to a possible interpretation of some controversial Aeschylus' verses, or without any doubt to the $4^{\text {th }}$ century B.C. It is particularly significant that the origin of the form 1.A, the simplest and more ancient one, has been related to Boeotia and Macedonia, passing immediately to Apulia, being these regions characterized by a social and military structure that exalted the equestrian aristocracy, as we can assume on the basis of the several and conspicuous panoplies. These aristocracies played a basic role in the social organization at the end of the Classical period and at the beginning of Hellenism.

The typological analysis of the muzzles allows us to distinguish between three groups: the first one, with the subtypes 1.A and 1.B, can be dated from the beginning of the $4^{\text {th }}$ century B.C.; its evolution can be observed considering some formal features with possible chronological implications that the lack of contexts prevents us from specifying. We notice the transformation of some elements of the type 1.A into the type 1.B, which lead us consequently to the type 2. The two bigger groups can be distinguished on the basis of the presence/absence of the bowl guard. A third muzzle's type, with a different shutting system, has not been found on the Iberian Peninsula.

The chronological range proposed for muzzles and openwork muzzles is considerably wide and needs to be corrected. So, the exemplar n. 1 from La Pedrera (Lleida) has been dated to the $6^{\text {th }}$ century B.C. because of the wrong dating of some bits associated, attributed to the type Szentes-Vekerzúg (Schüle, 1969: 46 and 126; Garcés, 2002: 200; 2007: 69), and, if dated correctly, to be lowered to the $4^{\text {th }}$ century (Graells, 2009, 2011). Another problem derived from the hypothesis of an Etruscan origin for the muzzle from Sangüesa (Navarra) (García y Bellido, 1931), due to a particular interpretation of its decoration. We refuse the Etruscan attribution and give an alternative interpretation, namely the Greek myth of the harpies fecundated by the wind Zephyr.

Even though for a consistent amount of muzzles and muzzles the archaeological context and the provenance are unknown, the exemplars from contexts define a restricted chronological frame: the muzzle from the Boeotian tomb, once revised, can be dated back to the beginning of the $4^{\text {th }}$ century, which is a good chronology for the two exemplars from the necropolis of La Pedrera (Lleida) (Graells, 2007, 2009, in press, 2011). The tomb painting of the Tomb 
of Makryghialos (Macedonia) is dated to the third quarter of the 4th century B.C. (Mannino, 2003: 715, tav. XXIII, 2-3).

Secondly, concerning the type 1.B, we have a well known context for the muzzle from Este, with a dating at the beginning of the $3^{\text {rd }}$ century B.C. This allows us to suppose a coherent chronological frame for both type 1.A and 1.B.

Finally, the type 2 do not have a good chronology and, in general, the exemplars known come from contexts dated to the centuries $3^{\text {rd }}-1^{\text {st }}$ B.C. Later, starting from the first period of the Roman Empire, the common muzzle was simplified in a decorated rhomboidal plaque tied up with perishable elements, thus determining the end of Hellenistic muzzles. The finding of an exemplar ascribable to the type 2 in the middle of the $19^{\text {th }}$ century in Pompeii has pushed the dating of this type down to the $1^{\text {st }}$ century A.D., although we must remember the presence of objects already «ancient» in the surroundings of Pompeii as the Vesuvius erupted (Lazzarini, Zevi, 1989; Bellelli, 1995). Coming back to the simple rhomboidal muzzle, it seemed to be known in Magna Graecia since the end of the $4^{\text {th }}$ century B.C., as showed by some Apulian paintings.

All the types of muzzle treated here may have had an origin in the Greek world, broadly speaking: the Aegean region and the Magna Graecia. From these territories the muzzle found diffusion among neighbour populations, especially the Italic ones, but reached even the Iberian Peninsula. For what concerns the Hispanic case, it is better to separate the «Iberian» context of La Pedrera ( $4^{\text {th }}$ century B.C.) from the muzzles of the type 2 , whose chronology is often Roman and among an historical background with external influence.

In order to explain how a Greek or a Greek-like exemplar could have reached the Iberian Peninsula, we can review some recent suggestions. Some scholars (Sánchez-Moreno, 2005: 238-239; Gabaldón, 2005: 268; Almagro-Gorbea, Torres, 1999) has underlined the importance of horse's role into the aristocratic exchanges during the proto-historical period, under peculiar circumstances in which even weapons, exogamic marriage and precious objects had a significant meaning. The horse, surely a valuable good, especially if his quality was accented, could represent undoubtedly a first-class diplomatic and tributary means. In this milieu, horses could have been obtained through more selective ways than the one of usual trades, especially as war chest or as exchanged status-symbols. The latter case could provide exotic objects of receiving power on long-distance trade routes; this fact could explain the heterogeneous composition of the panoply found inside the necropolis of La Pedrera, which included, among other objects, a falcata of big dimensions (Quesada, 2002b: 205-206) and an iron helmet of Alpine typology (Quesada, 2002a: 203-204; Graells, 2009, 2011).

A second option emphasizes the role achieved by the equites in some societies as incentive for a demand of precious objects (Bottini, 1989; LoPorto, 1996). Among Apulian and Messapian armies there was a proportion of 1:5 and, moreover, 1:3 between knights and children (Bottini, 1989: 710-711). If we believe to Titus Livius $(29,1,26)$, the approximate proportion of 1:7 was reached even by the Ilergetans during their resistance against Rome at the end of the $3^{\text {rd }}$ century B.C.; compared to all this, it is quite indicative the nature of the diplomatic present - 300 horses - given by Hasdrubal to the Ilergetan king Indibil after the battle of Baecula (Polib., 10, 40).

If we consider the fact that among the objects dated in the $4^{\text {th }}$ century B.C. found inside the necropolis of La Pedrera we do not have any imported vase, but we have imported weapons and foreign military equipments that could be explained by means of the activity of Ilergetan mercenaries (Graells, 2009, in press, 2011), this proposal awards the mercenaries of a role as introducers of elements connected to their activity. The hypothesis to explain the presence of such elements is based on the comparison with other contexts, which have allowed an inter- 
pretation of the weapons of La Pedrera as a panoply, probably assembled apart from the commercial trades, considering the absence of a significant trade of Mediterranean materials in the interior part of Catalonia during this period. For the groups including muzzles has been propo-

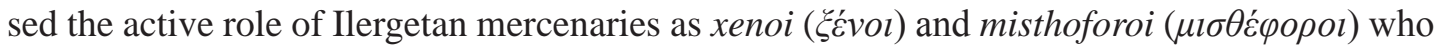
assembled the grave goods after several competitions with mercenaries of other origin and through the adoption of Mediterranean behaviours, like the accumulation of status symbols (mainly weapons) of different proveniences as expression of xenia ( $\xi \varepsilon v i \alpha)$ or philia ( $\varphi \imath \lambda i \alpha)$.

\section{BIBLIOGRAPHY}

AA. VV. (1958): Memorias del los Museos Arqueológicos, XV, 1954. Madrid, Ministerio de Educación Nacional.

AA. VV. (1990): Los bronces romanos en España. Madrid, Ministerio de Cultura.

Almagro, M. (1955): Museo Arqueológico de Barcelona, Guías de los Museos de España, 11. Madrid, Dirección General de Bellas Artes.

Almagro Gorbea, M. (2005): «Ideología ecuestre en la Hispania prerromana», Gladius, XXV: 151186.

Anderson, J.K. (1961): Ancient Greek Horsemanship. Berkeley - Los Angeles, University of California.

Argente, J.L.; Díaz, A.; Bescós, A. (2000): Tiermes V. Carratiermes, necrópolis celbérica. Campañas 1977 y 1986-1991. Valladolid, Arqueología en Castilla y León, 9.

Beazley, J.D. (1956): Attic Black-Figure Vase-Painters (=ABR). Oxford, Clarendon Press.

Bellelli, V. (1995): «Anomalie Pompeiane», Prospettiva, 77: 2-15.

Beltran Lloris, M. (2005): «Contrebia Belaiska (Botorrita, Zaragoza)», in AA.VV., Celtíberos. Tras la estela de Numancia. Soria, Junta de Castilla y León: 137-144.

Born, H., Hansen, S. (1994): Frühgriechische Bronzehelme, Sammlung Axel Guttmann, Band III, Verlag Philipp von Zabern, Mainz.

Borriello, M. (1999): «Finimento di cavallo», in A. Ciarallo, E. De Carolis (eds.): Homo faber. Natura, scienza e tecnica nell'antica Pompei, Napoli. Electa: 151.

Bottini, A. (1994): Armi, gli strumenti della guerra in Lucania. Bari.

Bozet, N. (2007a): «Muselière», in P. Cattelain, N. Bozet (eds.): Sur la piste du Cheval. De la Préhistoire à l'Antiquité, Malgré-Tout de Treignes, Belgique: 184, CEDARC.

Bozet, N. (2007a): «Muselière ouverte», in P. Cattelain, N. Bozet (eds.): Sur la piste du Cheval. De la Préhistoire à l'Antiquité, Malgré-Tout de Treignes, Belgique: 185, CEDARC.

Burkert, W. (1991): «La via fenicia e la via anatolica: Ideologie e scoperte fra oriente e occidente», Convegno per Santo Mazzarino, Roma (9-11 maggio 1991): 55-74.

Cabrera, P. (2005): «Hidria con la preparación de la cuadriga de Príamo», in Reflejos de Apolo. Deporte y arqueología en el Mediterráneo Antiguo, Madrid. Ministerio de Cultura y Museo de Almería: 148-149.

Charbonnet, A. (1986): «Le dieux aux lions d'Eretrie», AION, 8: 117-173.

Chippindale, Ch., Gill, D.W.J. (2000): «Material consequences of Contemporary Classical Collecting», AJA, 104, 3: 463-511.

Daremberg, Ch., Saglio, E. (1887): Dictionnaire des Antiquités Grecques et Romaines. Paris.

De Ridder, A. (1915): Les bronzes antiques du Louvre, II. Les instruments. Paris.

Donder, H. (1980): Zaumzeug in Griechenland und Cypern. Prähistorische Bronzefunde XVI.3. München.

Faklaris, P.N. (1985): «Pertrachelion», Arch. Delt., 40: 1-16.

Fales, F.M. (2006): «Rivisitando l'iscrizione aramaica dall'Heraion di Samo», in A. Naso (ed.): Straniere e non cittadini nei santuari greci. Firenze: 230-252.

Fiorini, L. (2006): «49.Hydria con scene di battaglia e preparazione di una quadriga per la partenza di un eroe», in A. Bottini, M. Torelli (a cura di): Iliade, Roma: 230-231. 
Gabaldón, M.M. (2003): «El caballo en el mundo celta. Significado y simbolismo de los équidos entre los pueblos galos», in F. Quesada, M. Zamora (eds.): El caballo en la Antigua Iberia. Madrid, Real Academia de la Historia: 219-240.

Garcés, I. (2002a): «Morrió de cavall», in J.L. Ribes (ed.): Sala d'Arqueologia de l'IEI. Catàleg, Lleida, IEI: 198-199.

Garcés, I. (2002b): «Fre de cavall», in J.L. Ribes (ed.): Sala d’Arqueologia de l'IEI. Catàleg, Lleida, IEI: $200-201$.

Garcés, I. (2007): «El empleo del ronzal caballar en el norte del Ebro durante la Edad del Hierro y la Época Ibérica», Gladius, XXVII: 67-84.

Garcés, I.; Junyent, E.; Lafuente, A.; López, J.B. (1997): Vilars 2000. Una fortaleza ilergeta d'ara fa 2700 anys. Universitat de Lleida.

García y Bellido, A. (1931): «Las relaciones entre el arte etrusco y el ibero», Archivo Español de Arte y Arqueología, 20: 119-148.

García-Bellido, M.P. (ed.) (1993): Álbum de dibujos de la colección de bronces antiguos de Antonio Vives Escudero. Madrid, Anejos de Archivo Español de Arqueología, 13.

García-Mauriño, J. (1993): «Los cascos de tipo Montefortino en la Península Ibérica», Complutum, 3: 95-146.

Gómez, X. (2003): «Fetos de équido en els Vilars (Arbeca, Lleida). Un nuevo tipo de deposición animal en hábitat durante la primera edad del hierro en Cataluña», in F. Quesada, M. Zamora (eds.): El caballo en la antigua Iberia. Estudio sobre los équidos en la edad del hierro. Madrid, BAH 19: 209-217.

Graells, R. (2007): «¿Culto heroico durante la primera edad del hierro e ibérico antiguo en el noreste peninsular? algunas consideraciones a partir del registro funerario», Cuadernos de Prehistoria y Arqueología de la Universidad Autónoma de Madrid, 33: 91-115.

Graells, R. (2009): Análisis de las manifestaciones funerarias en Catalunya durante los ss. VII y VI aC. Sociedad y Cultura Material: la asimilación de estímulos mediterráneos, Tesis Doctoral inédita, Universitat de Lleida.

Graells, R. (in press): «Interpretando los ajuares de las tumbas de caballo de la necrópolis de la Pedrera», Empúries.

Graells, R. (2011): «Mistophoroi Ilergetes: el ejemplo de las tumbas de Caballo de la necrópolis de la Pedrera (Vallfogona de Balaguer-Térmens, Catalunya, España)», JRGZM, 55:81-158.

Hazzard, R.A. (1992): «Did Ptolemy I get his Surname from the Rhodians in 304?», Zeitschrift für Papyrologie und Epigraphik, 93: 52-56.

Hyland, A. (1990): Equus. The horse in the Roman World. London.

Hyland, A. (2003): The horse in the Ancient World. Stroud.

Iles Johnston, S. (1992): «Xantus, Hera and the Erinyes (Iliad. 19.400-418)», Transactions of the American Philological Association, 122: 85-98.

Junyent, E., (2003): «L'albada de la civilització i els temps ilergets», in E. Junyent, A. Pérez, L'antiguitat, d'Iltirta a Ilerda, Història de Lleida, vol. I. Lleida, Pagès: 11-179.

Kyrieleis, H.G., Rölig, W. (1988): «Ein altorientalischer Pferderschmuck aus dem Heraion von Samos», MDAI (A), Paris, 103: 37-75.

Lageniere, J. (1997): «Note sur une muserolle disparue», in J. LaGenière (pres.): Héra. Images, espaces, cultes, Actes du Colloque International du Centre de Recherches Archéologiques de l'Université de Lille III et de l'Association P.R.A.C., Lille, 29-30 novembre 1993. Collection du Centre Jean Bérard 15: 262-265.

Lawson, A.K. (1978): «Studien zum Römischen Pferdegeschirr», Jahrbuch des Römisch-Germanischen Zentralmuseums Mainz, 25: 131-172.

Lazzarini, M.L., Zevi, F. (1989): «Necrocorinthia a Pompei: un'idria bronzea per le gare di Argo», Prospettiva, 53-56: 33-48.

Liesau Von Lettow-Vorbeck, C. (2005): «Arqueozoología del caballo en la Antigua Iberia», Gladius, XXV: 187-206.

Lippolis, E. (1995): «Mostra Atleti e guerrieri. Tradizioni aristocratiche a Taranto e nel mondo iapigio tra VI e V sec. a.C. (11 marzo 1994)», Taras, 15: 175-177.

Littauer, M.A.; Crouwel, J.H. (1979): Wheeled Veicles and Ridden Animals in the Ancient Near Est. Leiden, Brill. 
Loporto, F.G. (1996): «Tombe arcaiche di peuceti emergente», StAnt, 9: 7-36.

Maluquer de Motes, J. (1968): «Panorama económico de la Primera Edad del Hierro», in Primera reunión de Historia. Estudios de la Economía Antigua del Península Ibérica. Barcelona, Vicens Vives: 61-79.

Mannino, K. (2003): «L'iconografia del guerriero nel mondo apulo», in Atti del quarantreesimo convegno di studi sulla Magna Grecia: Alessandro il Molosso e i «condottieri» in Magna Grecia. Taranto-Cosenza (26-30 settembre 2003): 699-726.

Martín Tobías, R. (1958): «La necrópolis de La Pedrera», newspaper La Mañana. Lleida, 16 de abril de 1958.

Maya, J.L. (1986): «Incineració i ritual funerari a les valls del Segre i del Cinca», Cota Zero, 2: 39-47.

Maya, J.L. (1992): «Aprovechamiento del medio y paleoeconomía durante las etapas metalúrgicas del Nordeste peninsular», in R.A. Moure (ed.), Elefantes, ciervos y ovicaprinos. Universidad de Cantabria: 275-314.

Montanaro, A.C. (2007): Ruvo di Puglia e il suo territorio: le necropoli. I corredi funerari tra documentazione del XIX secolo e gli scavi moderni, Studia Archaelogica, 160, Roma.

Olmos, R. (2000): «Creciente lunar con la lucha de Heracles y Gerión, de Samos (Grecia)», in P. Cabrera, C. Sánchez (eds.): Los Griegos en España. Tras las huellas de Heracles. Madrid: 238.

Pallottino, M. (1952): La peinture étrusque, Ginebra.

Pernice, E. (1896): Griechisches Pferdegeschirr im Antiquarium der Königlichen Museen, 56, Winkelmannsprogramm.

Pita, R. (1975): Lérida ilergete-I. Lleida, Dilagro.

Plens, M. (1986): La necròpolis de la Pedrera (Vallfogona de Balaguer-Térmens). University of Lleida, Unpublished.

Plens, M.; Rafel, N. (2002): «La necròpoli de La Pedrera (Vallfogona-Térmens)», in J.L. Ribes (ed.): Sala d'Arqueologia de l'IEI. Catàleg. Lleida, IEI: 255-256.

Polito, E. (1998): Fulgentibus armis. Introduzione allo studio dei fregi d'armi antichi, Xenia Antiqua, 4. Roma.

Quesada, F. (1997): El armamento ibérico. Estudio tipológico, geográfico, funcional, social y simbólico de las armas en la Cultura Ibérica (siglos VI-I aC). Montagnac, Monographias Instrumentum 3.

Quesada, F. (2002a) «Casc» in J.L. Ribes (ed.): Sala d'Arqueologia de l'IEI. Catàleg. Lleida, IEI: 203204.

Quesada, F. (2002b) «Falcata» in J.L. Ribes (ed.): Sala d'Arqueologia de l'IEI. Catàleg. Lleida, IEI: 205-206.

Quesada, F. (2005): «El gobierno del caballo montado en la Antigüedad clásica con especial referencia al caso de Iberia. Bocados, espuelas y la cuestión de la silla de montar, estribos y herraduras», Gladius, XXV: 97-150.

Ripoll, E. (1959): «El poblado y la necrópolis ilergetas de 'La Pedrera' (Vallfogona de Balaguer, Lérida)», Ampurias, XXI: 275-281.

Ripoll, E.; Batista, R.; Carreras, T. Llecha, M.T.; Llongueras, M.; Petrus, M.; Sanmartí, E.; Vilaseca, L. (1981): Guía del Museo Arqueológico de Barcelona, Guías, 3. Diputación de Barcelona.

Rolley, Cl. (1983): Les bronzes grecs, Office du Livre, Fribourg, Editions Vilo, Paris.

Sánchez-Moreno, E. (2005): «Caballo y sociedad en la Hispania céltica: del poder aristocrático a la comunidad política», Gladius, XXV: 237-264.

Schüle, W. (1969): Die Meseta-Kulturen der Iberischen Halbinsel, Madrider Forschungen, 3. Berlin.

Schwinden, L. (1987): «Zur Trageweise der Metallhackamore bei römischen Pferden», Funde und Ausgrabungen im Bezirk Traer, 19: 36-41.

Siret, L. (1906): Villaricos y Herrerías. Antigüedades púnicas, romanas, visigóticas y árabes. Memoria descriptiva é histórica, Madrid. Real Academia de la Historia. Ed. facsímil, 1985, Madrid.

Soriano, R. (1991): Catálogo de Fondos Prehistóricos, Serie Arqueológica, 7. Valencia.

Taylor, A.K. (1975): «Römische hackamoren und Kappzäume aus metall», Jahrbuch des RömischGermanischen Zentralmuseums Mainz, 22: 106-133.

Vigneron, P. (1968): Le cheval dans l'antiquité. Université de Nancy. 
Von Bothmer, D. (1990): Glories of the Past, Ancient Art from the Shelby White and Leon Levy Collection, Metropolitan Museum, New York.

Walters, H.B. (1899): Catalogue of Bronzes Greek, Roman and Etruscan in the Department of Greek and roman antiquities, British Museum. London.

Recibido: 03/02/2011

Aceptado: 01/06/2011 